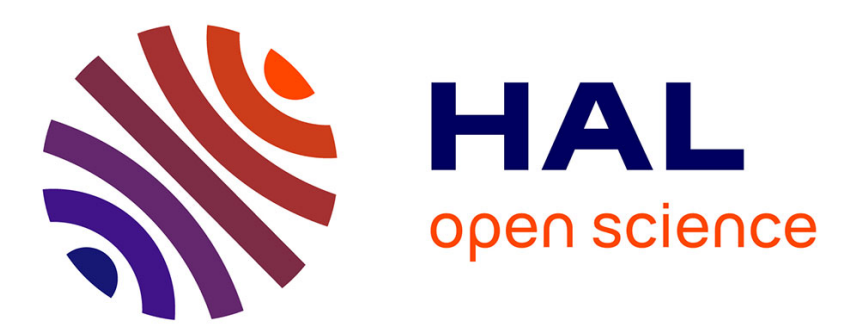

\title{
Control Rights, Pyramids, and the Measurement of Ownership Concentration
}

Jeremy S.S. Edwards, Alfons J. Weichenrieder

\section{To cite this version:}

Jeremy S.S. Edwards, Alfons J. Weichenrieder. Control Rights, Pyramids, and the Measurement of Ownership Concentration. Journal of Economic Behavior and Organization, 2009, 72 (1), pp.489. 10.1016/j.jebo.2009.05.016 . hal-00701897

\section{HAL Id: hal-00701897 \\ https://hal.science/hal-00701897}

Submitted on 28 May 2012

HAL is a multi-disciplinary open access archive for the deposit and dissemination of scientific research documents, whether they are published or not. The documents may come from teaching and research institutions in France or abroad, or from public or private research centers.
L'archive ouverte pluridisciplinaire HAL, est destinée au dépôt et à la diffusion de documents scientifiques de niveau recherche, publiés ou non, émanant des établissements d'enseignement et de recherche français ou étrangers, des laboratoires publics ou privés. 


\section{Accepted Manuscript}

Title: Control Rights, Pyramids, and the Measurement of Ownership Concentration

Authors: Jeremy S.S. Edwards, Alfons J. Weichenrieder

PII: $\quad$ S0167-2681(09)00151-6

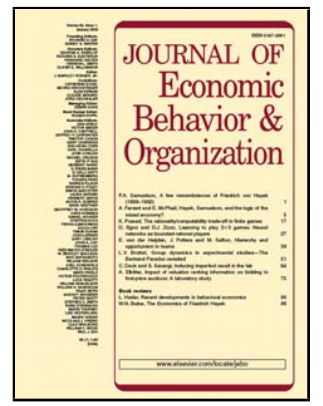

DOI: $\quad$ doi:10.1016/j.jebo.2009.05.016

Reference: $\quad$ JEBO 2402

To appear in: Journal of Economic Behavior \& Organization

Received date: 6-6-2007

Revised date: $\quad$ 13-5-2009

Accepted date: $\quad$ 14-5-2009

Please cite this article as: Edwards, J.S.S., Weichenrieder, A.J., Control Rights, Pyramids, and the Measurement of Ownership Concentration, Journal of Economic Behavior and Organization (2008), doi:10.1016/j.jebo.2009.05.016

This is a PDF file of an unedited manuscript that has been accepted for publication. As a service to our customers we are providing this early version of the manuscript. The manuscript will undergo copyediting, typesetting, and review of the resulting proof before it is published in its final form. Please note that during the production process errors may be discovered which could affect the content, and all legal disclaimers that apply to the journal pertain. 


\title{
Control Rights, Pyramids, and the Measurement of Ownership Concentration*
}

\author{
Jeremy S.S. Edwards \\ University of Cambridge \& CESifo
}

Alfons J. Weichenrieder

Goethe University Frankfurt, Oxford University Centre for Business Taxation \& CESifo

May 2009

Addresses of authors

Jeremy S.S. Edwards

Faculty of Economics

University of Cambridge

Sidgwick Avenue

Cambridge CB3 9DD

United Kingdom

Tel: ++44 1223335232

Fax: ++44 1223335475

Email: je12@cam.ac.uk

* Corresponding Author
Alfons J. Weichenrieder*

Goethe University Frankfurt

Grüneburgplatz 1

(Box RuW 45)

60323 Frankfurt (Main)

Germany

Tel: ++4969798 34788

Fax: ++496979835015

Email: a.weichenrieder@em.uni-frankfurt.de

\footnotetext{
* We thank Dennis Leech for allowing us to use his algorithms for computing voting power indices and for his helpful comments. We also thank Sheilagh Ogilvie and two anonymous referees for helpful comments, and Mara Faccio and Larry Lang for allowing us to use their unpublished data.
} 


\title{
Control Rights, Pyramids, and the Measurement of Ownership Concentration
}

\begin{abstract}
The recent corporate governance literature has emphasised the distinction between control and cash-flow rights but has disregarded measurement issues. Control rights may be measured by immediate shareholder votes, the voting rights as traced through ownership chains, or voting power indices that may or may not trace ownership through chains. We compare the ability of various measures to identify the effects of ownership concentration on share valuation using a German panel data set. The widely-used weakest link principle does not perform well in this comparison. Furthermore, measures that trace control through ownership chains do not outperform those that rely on immediate ownership, thus questioning the role of pyramids in the separation of control and cash-flow rights. The paper emphasises that there is a distinction between these two aspects of ownership even without pyramids or preferred stock, identification of which requires measures that, like the ShapleyShubik index, do not simply equate control rights with voting rights.
\end{abstract}

JEL Classification Numbers: G32, G34

Keywords: Control rights, Cash-flow rights, Pyramids, Ownership structure 


\section{Introduction}

In most countries the typical listed firm is controlled by one or two large owners (Claessens et al. 2000, Faccio and Lang 2002). The key conflict of interest in the governance of such firms is not between dispersed shareholders and professional managers who run the firm with little or no ownership stake in it, but rather between controlling and non-controlling owners. The extent of this conflict depends on the relationship between the control and cash-flow rights of the controlling owner (Shleifer and Vishny 1997, La Porta et al. 1999, Bebchuk et al. 2000, La Porta et al. 2002, Becht et al. 2003). The control rights of ownership refer to an owner's ability to influence the way a firm is run, while the cash-flow rights of ownership refer to the fraction of the firm's profits to which an owner is entitled. ${ }^{1}$ Other things equal, the greater the control rights of the controlling owner, the greater her ability to obtain private benefits of control at the expense of other owners. Higher control rights for the controlling owner are usually regarded as increasing her ability to obtain private benefits of control at the expense of other owners. Evidence of such private benefits of control has been provided by Barclay and Holderness (1989), Bergström and Rydqvist (1990), Zingales (1994), Johnson et al. (2000), Franks and Mayer (2001), Bertrand et al. (2002), Gugler and Yurtoglu (2003), Nenova (2003), and Dyck and Zingales (2004). However, the greater the cash-flow rights of the controlling owner, the more closely her incentives will be aligned with those of the other owners, and hence the lower her incentives to pursue costly policies which divert profits from noncontrolling owners (Jensen and Meckling, 1976). Thus the conflict of interest is likely to be more severe when the divergence between the controlling owner's control and cash-flow rights is greater.

The measurement of cash-flow rights is conceptually straightforward, but that of control rights is not. The extent of control that an owner has over a firm depends on various factors, but primarily on that owner's ability to influence the outcome of a vote by all owners. This can be measured in several ways, which yield very different results, as we show in the paper. The absence of an unambiguously correct measure of control rights means that, in order to be convincing, the conclusions of empirical

\footnotetext{
${ }^{1}$ There are no universally-agreed terms for these concepts in the literature: control rights and cash-flow rights are alternatively called control and ownership respectively.
} 
studies of the conflict of interest between controlling and non-controlling owners must be robust to different measures of control rights.

However, the recent literature on ownership and corporate governance has focussed on a single control-rights measure. Most of this literature has equated control rights with voting rights. ${ }^{2}$ If control and voting rights are treated as equivalent, then there are two main ways in which the control and cash-flow rights of ownership can be separated. One is by issuing classes of shares that differ in terms of their relative proportion of voting rights and dividend entitlement. The other is for an owner to exercise control via a chain of other firms - a pyramid. Suppose that all shares have the same dividend entitlement and voting rights, and possession of a simple majority of the voting rights allows an owner to determine all firm decisions. Then if an owner has 60 per cent of the voting rights in firm $\mathrm{A}$, which has 55 per cent of the voting rights in firm $\mathrm{B}$, this pyramid structure gives the owner complete control of firm $\mathrm{B}$ despite having cash-flow rights of only 33 per cent (the product of the owner's cashflow rights in firms A and B). In practice, pyramids are much the most important of these two ways of separating control and cash-flow rights, and have therefore played a central role in recent empirical studies of the separation of control and cash-flow rights. But the way in which these studies have measured the control rights of ultimate owners (those at the apex of a pyramid) is questionable. They have typically done so using the weakest-link principle (henceforth WLP). This principle assigns control rights to the ultimate owner on the basis of the minimum value of voting rights across the different links of a control chain. Thus, in the example above, the WLP would assign the ultimate owner control rights of 55 per cent in firm B. In cross-country comparisons the WLP has the advantage that it is comparatively easy to implement as all shareholdings below a generous threshold can be ignored and different national disclosure rules become largely irrelevant (La Porta et al. 1999, pp. 475-6). However, it is an ad hoc measure with no theoretical underpinning, and thus has some potentially serious problems as a measure of control rights. Furthermore, the recent empirical literature has simply taken for granted that the WLP produces satisfactory measures of control rights and their separation from cash-flow rights: the measures based on the WLP have not been compared to other possible control-right measures.

\footnotetext{
${ }^{2}$ Examples include La Porta et al. (1999), Claessens et al. (2000), Faccio and Lang (2002), Claessens et al. (2002), La Porta et al. (2002) and Laeven and Levine (2006).
} 
In this paper we use voting power indices to provide alternative measures of control rights that can be employed in empirical studies of ownership and corporate governance. These indices provide measures of the ability of a voter holding a given proportion of voting rights to determine the outcome of a vote, given the overall proportion required to win and the distribution of other voters' rights (Felsenthal and Machover 1998). They thus provide natural measures of control rights. The use of such indices to measure control rights has two major advantages. First, they can distinguish control from cash-flow rights even when all shares have the same voting and dividend rights and no owner exerts control through a pyramid. It is far from obvious that in such a case an owner who holds, say, 60 per cent of the shares has equal control and cash-flow rights. This owner can determine the outcome of all decisions made by majority vote of the owners. Unless some decisions require more than 60 per cent of the votes, this owner has complete control despite having only 60 per cent of the cash-flow rights in the firm. Measuring control rights by a voting power index will reveal this difference. Second, the approach provides a basis for alternatives to the WLP measure of the control rights of owners who exercise control via a pyramid. These advantages make it possible both to evaluate the robustness of conclusions based on the WLP, and to study the effects of large owners' control and cash-flow rights empirically without having to rely on the existence of pyramids and different classes of share to obtain distinct measures of such rights.

This paper provides three main insights. First, most of our measures of ownership concentration can be used to identify a statistically and economically significant effect of ownership concentration on share valuation for our sample of German firms that is in line with corporate governance models. However, this is not the case for the WLP. This raises doubts about the conclusions that have been drawn solely on the basis of the WLP measure. Second, measures that trace control through ownership chains do not outperform those that rely on immediate ownership at the first-tier level. This questions the widely-held view that pyramids play an important role in separating control and cash-flow rights of large owners. Third, the paper emphasises that there is a distinction between control and cash-flow rights even without pyramids or preferred stock, identification of which requires measures that, like the Shapley-Shubik index, do not simply equate control rights with voting rights. 
Section 2 of the paper discusses the problems that arise in using the WLP as a measure of ultimate owners' control rights and the way in which control rights can be measured on the basis of voting power indices. Section 3 uses a sample of listed German firms to compare different control-rights measures. It shows that the degree of control exercised by large owners and the extent of the divergence between control and cash-flow rights are very sensitive to the measure of control rights that is adopted. To assess whether the differences between these alternative measures are of any consequence, Section 4 compares their performance as explanatory variables in a regression model of the determinants of a firm's market-to-book ratio of equity value. The results show that different ownership measures do result in different conclusions about the effects of the largest owner's control and cash-flow rights on firm value. The results also suggest that the WLP measure is unsatisfactory and that measures of the divergence between the largest owner's control and cash-flow rights which take account of pyramids perform generally less well than those that do not. Section 5 concludes by noting that the conceptual problems which arise with the use of the WLP to measure control rights and its poor performance in our empirical analysis mean that the results of studies of ownership concentration and corporate governance based exclusively on the WLP, such as the claim by La Porta et al. (1999) that the use of pyramids is a major reason why the control rights of largest owners exceed their cash-flow rights, must be regarded as tentative in the absence of evidence that they are robust to alternative control-right measures. Section 5 suggests that the emphasis on pyramids as a method of separating control from cash-flow rights in recent studies may be misplaced.

\section{Measures of control rights}

\subsection{The weakest-link principle}

The WLP approach to measuring the control rights of ultimate owners appears to originate with La Porta et al. (1999), but much of the detail of this approach has been developed in the course of its application by Claessens et al. (2000), Claessens et al. (2002), Faccio and Lang (2002), and Faccio et al. (2001). According to the WLP, a firm has an ultimate owner if a controlling owner with more than some threshold 
value of voting rights can be identified. The threshold value used in different applications has variously been five, 10 or 20 per cent. A firm is said to have an ultimate owner at a given threshold if all the links in the relevant control chain exceed the threshold value. According to this approach, a firm is widely held if no ultimate owner can be identified using the WLP and the relevant threshold value of voting rights. Faccio and Lang (2002, page 372) illustrate the approach as follows:

if a family owns $15 \%$ of Firm $\mathrm{X}$, that owns $20 \%$ of Firm $\mathrm{Y}$, then $\mathrm{Y}$ is controlled through a pyramid at the $10 \%$ threshold. However, at the $20 \%$ threshold, we would say that Firm Y is directly controlled by Firm X (which is widely held at the $20 \%$ threshold) and no pyramiding would be recorded.

The links in the control chain that are recognised when measuring ultimate ownership via a pyramid are those where voting rights are less than 100 per cent. If, in Faccio and Lang's example, the family had all the voting rights in Firm X, then Firm Y would be said to be directly controlled by this family, with no pyramid involved.

There is no theoretical foundation for the use of the WLP to measure ultimate owners' control rights, and hence a number of problems arise in its application. Some of these reflect not the existence of pyramids but rather the drawbacks common to all approaches that treat control and voting rights as identical. The use of threshold values above which owners' voting rights are regarded as giving control and below which they are not is inevitably arbitrary, and leads to counter-intuitive outcomes. It is difficult to accept, for example, that a firm is widely held if it has a single large owner holding 19 per cent of the voting rights with the other 81 per cent being dispersed over very many small owners, as is implied by the use of a 20 per cent threshold.

However, the particular problems of the WLP concern its application to pyramids. Consider first the following two control chains. In one, ultimate owner 1 has 26 per cent of the voting rights in firm A, which has 25 per cent of the voting rights in firm B. In the other, ultimate owner 2 has 90 per cent of the voting rights in firm $\mathrm{C}$, which has 25 per cent of the voting rights in firm D. It seems natural to regard ultimate owner 2 as having greater control rights in firm D than ultimate owner 1 has in firm B. Although the two intermediate firms have identical voting rights in the firms at the bottom of the control chains, ultimate owner 2 is guaranteed to win any majority vote of firm C's owners while ultimate owner 1 is not guaranteed victory in a 
majority vote of firm A's owners. But, according to the WLP, the control rights of 1 in firm B and 2 in firm D are identical, at 25 per cent. Now consider two further control chains. In one, ultimate owner 3 has 25 per cent of the voting rights in firm E, while in the other, ultimate owner 4 has 25 per cent of the voting rights in firm F, which has 25 per cent of the voting rights in firm G, which has 25 per cent of the voting rights in firm $\mathrm{H}$, which has 25 per cent of the voting rights in firm I. In this case it seems natural to regard ultimate owner 3 as having greater control rights in firm $\mathrm{E}$ than ultimate owner 4 has in firm I, but the WLP assigns equal control rights in the firms at the bottom of the respective control chains to owners 3 and 4 . The major problem with the WLP is that, in certain cases, it fails to produce measures of control rights that correspond with any reasonable notion of what ultimate owners' control rights are.

A second problem with the WLP arises when there are two or more ultimate owners in a control chain, because it is unclear how to incorporate multiple owners into the WLP. The difficulty is illustrated in Figure 1. There are four ultimate owners of firm $\mathrm{J}$ (individuals 5-8). These individuals have voting rights as shown in firms $\mathrm{K}$ and L, each of which has half the voting rights in firm J. If the control rights of each individual in firm $\mathrm{J}$ are measured by applying the WLP, they are as follows: 25 per cent for individual 5, 50 per cent for individual 6, 50 per cent for individual 7 and 40 per cent for individual 8 . Total control rights are therefore 165 per cent. If total control rights are, reasonably, required to sum to 100 per cent, it is not possible to measure the control rights of multiple owners by applying the WLP to each owner.

When the WLP method employed by La Porta et al. identifies more than one ultimate owner, they "assign control to the shareholder with the largest ... voting stake". ${ }^{3}$ But ignoring the existence of more than one ultimate owner with significant control rights can be very misleading. Faccio et al. (2001) use the WLP and a threshold value of 20 per cent for voting rights to identify the largest ultimate owner in firms in their sample. They find that 45.3 per cent of the European firms in their sample with such a controlling owner had another ultimate

\footnotetext{
${ }^{3}$ La Porta et al. (1999), page 478, definition of widely-held.
} 
Figure 1: Hypothetical ownership structure for a firm owned via a pyramid

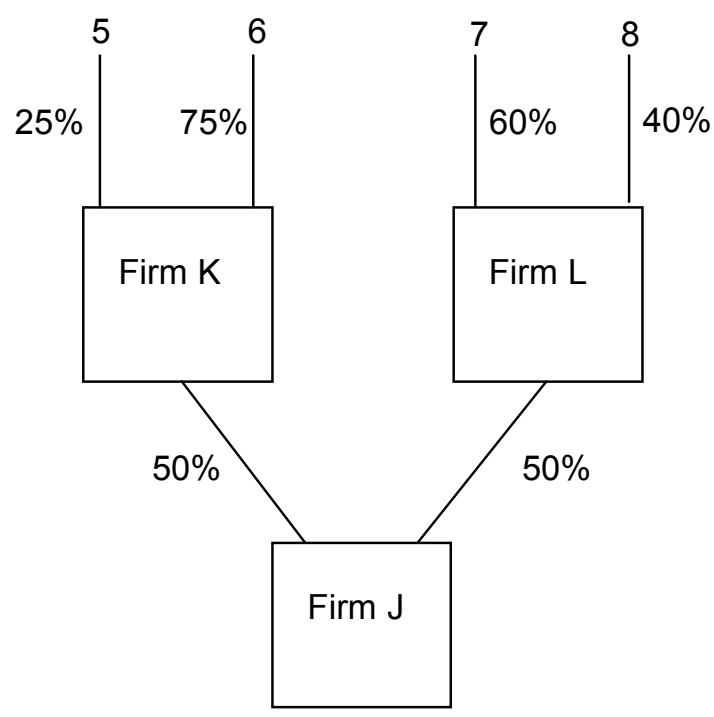

owner with at least 10 per cent of the voting rights. Among the Asian firms in their sample, 32.2 per cent of firms were in this position. It is clear that, in a significant minority of cases, there are possible limitations on the control rights of the largest owner arising from the existence of other large owners, and thus the La Porta et al. approach is not appropriate.

The other authors who have used the WLP to measure ultimate owners' control rights do take some account of the existence of multiple large owners, but the way in which this is done is questionable. When a firm has more than one ultimate owner at a particular threshold value, the method adopted is to divide overall control of the firm equally among these owners. Claessens et al. (2000, page 95) give an example of a firm where a family has 30 per cent of the voting rights and a widelyheld corporation has 10 per cent of the voting rights: "at the $10 \%$ cutoff the family and the corporation are each assigned one-half of the ultimate control. At the $20 \%$ level, however, the firm is fully controlled by the family". It is difficult to see how this approach can be justified. Either it gives too much control to the corporation - at the 10 per cent threshold, the corporation is assigned the same degree of control as the family despite having only one-third of the voting rights - or it gives too little - at the 20 per cent threshold, the corporation is assigned no control despite having a non- 
trivial share of the voting rights. In practice, the empirical work of these authors has focussed on the values of the largest ultimate owner's control and cash-flow rights, and the presence of other large owners is reflected only by identifying cases where such owners exist, rather than by a plausible adjustment of the value of the largest owner's control rights. Thus Claessens et al. (2000) and Faccio and Lang (2002) both report the proportion of firms in which there are multiple large owners, while Faccio et al. (2001) use a multiple owners dummy variable in their analysis of dividend payouts. This limited use of the WLP in cases where there are multiple large owners of firms reflects the fact that the WLP has no theoretical foundation and thus cannot be adapted to the task of providing numerical values for the control rights of several different ultimate owners of a given firm.

The application of the WLP is also far from obvious in the case of crossholding: situations in which a firm in a control chain has some voting rights in another firm higher up the control chain. The procedure adopted by Claessens et al. (2000, page 93) is as follows:

Suppose that a shareholder has $25 \%$ of the voting rights in firm A, which owns $100 \%$ of firm B. Firm B in turn owns $50 \%$ of firm A. What share of the voting rights does the shareholder have in firm A? Following our definition of control, we determine that the shareholder has $50 \%$ of the control rights in firm A, $25 \%$ directly and $25 \%$ through a pyramidal chain.

But it can be argued that the figure of 50 per cent greatly overstates the control rights of the shareholder in this example. Suppose that the management of firm B differs from the shareholder in its views about the policies that firm A should adopt. Since the management of firm B has 50 per cent of the voting rights in firm A, it can never lose a majority vote of firm A's owners, and will typically win. The shareholder's control rights in firm A thus appear to be far smaller than the figure assigned by the WLP.

The WLP thus has a number of serious problems as an approach to measuring ultimate owners' control rights. An alternative approach, based on voting power indices, is therefore worth exploring. 


\subsection{Voting power indices}

Voting power indices provide a natural basis for measurement of the control rights of owners of a firm. These indices have been used in some studies of corporate governance (Leech 1988, 2002, Pohjola 1988, Rydqvist 1986, Zingales 1994, Zwiebel 1995), but have not been applied to the measurement of control rights exerted through a pyramid. The two best-known voting power indices are those developed by Shapley and Shubik (1954) and Banzhaf (1965). The Shapley-Shubik index (hereafter SSI) measures a voter's ability to influence the outcome of a vote by making a voter's power proportional to the number of times that voter is pivotal in a sequential coalition of voters, i.e., the number of times that voter changes a sequential coalition from a losing to a winning one by entering it. A sequential coalition is one formed by adding one voter at a time, with the order in which voters enter being important. The SSI for a particular voter is the number of times that voter is pivotal divided by the number of times all voters are pivotal. The Banzhaf voting power index (hereafter BZI) measures a voter's ability to influence the outcome of a vote by making voting power proportional to the number of times that voter is a critical voter, i.e., the number of times that voter changes a coalition that has enough votes to win into a losing one by leaving it.

Although voting power in a given situation may be the same whether measured by the SSI or the BZI, in general the two indices give different results. Suppose that a firm has a single large shareholder, with 40 per cent of the votes, and 60 small shareholders each owning one per cent of the votes. The outcome of a vote is determined by simple majority, so that the quota required to win is 50 per cent. In this case, the SSI for the large shareholder is 65.61 per cent, while each small shareholder has a SSI of 0.57 per cent. In contrast, the BZI for the large shareholder is 100 per cent, and each small shareholder has a BZI of zero.

The fact that the SSI and the BZI often give substantially different measures of the voting power associated with a given distribution of voting rights may be one reason why these indices are not more widely used as measures of voting power. Another reason may be that the theoretical foundations of the two indices are not 
clear-cut. ${ }^{4}$ In this paper, no attempt is made to resolve the question of which voting power index is theoretically preferable. Instead, the paper uses the SSI rather than the BZI as the basis of an alternative to the WLP as a measure of control rights for the following practical reason.

A problem that often arises when voting power indices are used to measure the control rights of firm owners is that not all ownership stakes are observed, and hence assumptions must be made about the unobserved voting rights. The unobserved voting rights are usually individually very small, although they may be large in aggregate, so a natural assumption to make is that the total unobserved voting rights are dispersed over an infinitely large number of owners. This case is known as the oceanic one in the literature on voting power indices: there exists a large number (in the limit, an ocean) of 'minor' voters with positive total voting rights, but the voting rights of each individual minor voter tend to zero. The values given by the SSI are not very sensitive to the assumption made about unobserved voting rights, but this is not true for the BZI, and the SSI and BZI behave very differently in the oceanic case, as Dubey and Shapley (1979) show. If there is a single large owner holding a fraction $\mathrm{x}<0.5$ of the voting rights, the remaining fraction 1- $\mathrm{x}$ is held by an ocean of small owners, and the quota is 50 per cent, then the SSI for the large owner is $\mathrm{x} /(1-\mathrm{x})$, while the BZI is always 100 per cent. ${ }^{5}$ Thus if a firm has a single large owner holding five per cent of the voting rights, and an ocean of small owners holding the remaining 95 per cent, the SSI for the large owner is 5.26 per cent but the BZI is 100 per cent. If the 95 per cent is held by 190 owners each with 0.5 per cent of the votes rather than by an ocean of small owners, the SSI for the large owner is 5.24 per cent, while the BZI is 5.91 per cent. The value of the BZI is thus extremely sensitive to the assumption made about the unobserved voting rights, and the assumption that these are held by an ocean of small owners may not be appropriate when using the BZI. In the absence of a compelling alternative, however, the oceanic assumption is used in this paper, and therefore the BZI is not used to compute measures of control rights.

\footnotetext{
${ }^{4}$ Felsenthal and Machover (1998) suggest that the two indices correspond to different conceptions of power.

${ }^{5}$ The general result is that the BZIs for the major voters in a situation with an ocean of minor voters are given by the BZIs for a different voting game, in which the only voters are the major voters and the fraction of votes required to win is equal to that in the original game less half the fraction of votes held by the ocean. See Dubey and Shapley (1979, pp. 110-118) for a full discussion.
} 
An obvious advantage of using the SSI to measure the control rights of firm owners is that control and cash-flow rights can be distinguished even when all shares have the same voting and dividend rights and no owner exerts control through a pyramid. Consider the example above of the firm with a single large owner holding 40 per cent of the votes, and 60 small owners each holding one per cent of the votes. Suppose that all shares have the same voting and dividend rights. If control rights are measured by voting rights, then the large owner has control and cash-flow rights of 40 per cent, and each small owner has control and cash-flow rights of one per cent. However, if control rights are measured by the SSI, and the quota is 50 per cent, then the largest owner has control rights greater than cash-flow rights (65.61 per cent compared to 40 per cent) and each small owner has control rights less than cash-flow rights ( 0.57 per cent compared to one per cent).

Another advantage of using the SSI is that it provides the basis for an alternative to the WLP as a measure of the control rights of firm owners who exercise control via a pyramid. Consider an example in which firm $\mathrm{M}$ has a single large owner, firm $\mathrm{N}$, which has 15 per cent of the voting rights, while the remaining 85 per cent are dispersed among an ocean of small shareholders. Suppose that firm $\mathrm{N}$ is owned by three individuals $(9,10$ and 11) with voting rights of 50 per cent, 39.9 per cent and 10.1 per cent respectively. There is only one chain of control in this example, which leads to three ultimate owners. The WLP as used by La Porta et al. would treat firm M as widely held if a threshold value of 20 per cent were used. If a 10 per cent threshold were used, then the ultimate owner of firm $\mathrm{M}$ would be individual 9, with control rights of 15 per cent. Since La Porta et al. explicitly eschew the use of measures of ownership concentration and focus instead on identifying a single owner with effective control, they would assign a value of zero to the control rights of shareholders 10 and 11 in firm $\mathrm{N}$, and hence in firm M. This is not easily justifiable. The approach of the other authors who have used the WLP would be to recognise the existence of multiple ultimate owners of firm $\mathrm{M}$ at a 10 per cent threshold value, and say that this firm was one-third controlled by each of the three individuals, but it is unclear what numerical values would be assigned to their control rights under this approach. 
An alternative approach is to use the SSI to calculate the voting power of owners at each tier in the control chain, and then calculate the product of these voting power values at different tiers to obtain measures of the control rights of all ultimate owners. In the example just discussed, assuming that votes are decided by simple majority, the SSI of firm N's voting power in firm M is 17.65 per cent. Individual 9 has voting power of 66.67 per cent in firm $\mathrm{N}$ according to the SSI, while individuals 10 and 11 each have voting power of 16.67 per cent. Calculating the product of the relevant SSIs, individuals 9, 10 and 11 have voting power in firm $\mathrm{M}$ of 11.77 per cent, 2.94 per cent and 2.94 per cent respectively. According to the SSI, the remaining 82.35 per cent of the voting power in firm $M$ belongs to the ocean of small shareholders, each of which has infinitesimally small voting rights.

Measures of ultimate owners' control rights constructed in the way described in the previous paragraph, although based on the SSI, are not equivalent to the SSIs for the compound voting game formed by a pyramid of firms in which control depends on the ability to win several different votes. The SSI for a compound voting game is not, in general, equal to the product of the SSIs at each level of the game. Owen (1995, page 276) shows that the only non-trivial voting power index for a compound voting game that can be obtained as the product of the corresponding indices at each level of the game is the BZI. However, as we have noted, the BZI is not a satisfactory index of voting power for oceanic voting games, and we do not use it to measure firm owners' control rights. It is not straightforward to compute SSIs for compound voting games, and we therefore measure the control rights of ultimate owners by the product of SSIs at each tier of a pyramid, since this can be calculated straightforwardly. We call the resulting measures SSI-based ultimate owner control rights. We recognise that our SSI-based measures of ultimate owners' control rights are open to the objection that they are not the same as true SSI measures derived from the compound voting game formed by a pyramid. But our measures are straightforward to compute, and they do provide plausible alternatives to the WLP control right measures, as the following example shows. 


\subsection{An example: Linotype-Hell}

A specific example of the differences between these approaches to the measurement of control rights is provided by the case of Linotype-Hell, one of the German firms in our sample. Figure 2 illustrates the ownership of this firm in 1991-3. The largest voting block (33.33 per cent) was held by Siemens AG (a corporation), ${ }^{6}$ while the second-largest holder of voting rights was the firm Frega, with 16.67 per cent. The remaining voting rights were dispersed. Of the voting rights in Siemens, 10 per cent were owned by the Siemens family, with the rest again being dispersed. Of the voting rights in Frega, 40 per cent were owned by Commerzbank, with three other owners each having 20 per cent.

Figure 2: Ownership of Linotype-Hell

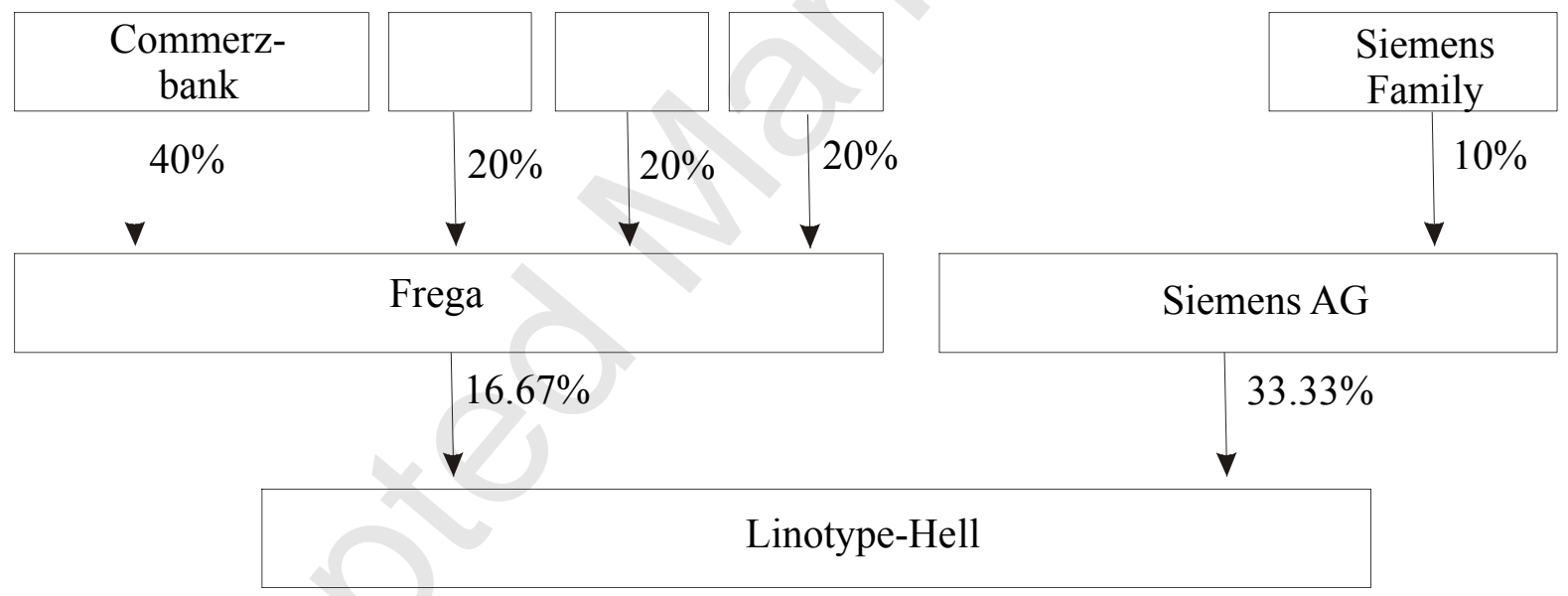

At threshold values of both 10 and 20 per cent, the La Porta et al. version of the WLP would say that there was a single ultimate owner of Linotype-Hell: the Siemens family with control rights of 10 per cent. The other version of the WLP would say that the Siemens family was the sole ultimate owner of Linotype-Hell at the 20 per cent threshold, but at the 10 per cent threshold five ultimate owners of Linotype-Hell would be identified, each having one-fifth control, although it is not clear what precise value of control rights each ultimate owner would be assigned. It does not seem to be defensible to ignore the existence of the control chain in Linotype-Hell associated with Frega and assign all control to the Siemens family. But it is also far from obvious that the Siemens family, Commerzbank and the three other

\footnotetext{
${ }^{6}$ AG stands for Aktiengesellschaft (stock corporation).
} 
owners of Frega have equal control rights in Linotype-Hell, even if it was clear what precise value these control rights took. Neither version of the WLP produces intuitively plausible values for the control rights of Linotype-Hell's ultimate owners.

Now consider the SSI-based and BZI measures of ultimate owner control rights for Linotype-Hell. Assuming that decisions are made by simple majority voting and the unobserved shareholdings are distributed among an ocean of small shareholders, Siemens AG has a SSI of 44.44 per cent in Linotype-Hell and Frega has a SSI of 11.12 per cent. The Siemens family has a SSI of 11.11 per cent in Siemens AG. Commerzbank has a SSI of 50 per cent in Frega, and the other three owners of Frega each have an SSI of 16.67 per cent. Thus, according to the SSI-based measure, the control rights of the Siemens family in Linotype-Hell are 4.94 per cent, while those of Commerzbank are 5.56 per cent. The other three ultimate owners of Linotype-Hell have control rights of 1.85 per cent according to the SSI-based measure. In this case, the SSI-based measure of ultimate owners' control rights produces an intuitively plausible result, namely that although it is hard to say which of Commerzbank and the Siemens family has the larger control rights in Linotype-Hell, these two ultimate owners have greater control rights than the other three. According to the BZI, however, Siemens AG has 100 per cent of the voting power in LinotypeHell, and the Siemens family has 100 per cent of the voting power in Siemens AG, so the Siemens family has all the control rights in Linotype-Hell and Commerzbank has none. Although it is straightforward to compute the BZIs for the compound voting game constituted by Linotype-Hell, the resulting control-rights measures are not intuitively plausible, because of the behaviour of the BZI in the oceanic case. The example of Linotype-Hell illustrates why we decided not to compute control-rights measures using the BZI in the analysis presented in this paper.

This section has shown that the use of the WLP to measure the control rights of ultimate owners suffers from several problems, and that an alternative approach to the measurement of such control rights exists, based on the SSI. It has also pointed out that measuring control rights by the SSI allows them to be distinguished from cash-flow rights even when all shares have the same voting and dividend rights and there are no pyramids. Whether these different approaches yield significantly different measures of control rights is the subject of the next section. 


\section{Control-rights measures for listed German firms}

To analyse the extent to which different approaches to measurement of control rights yield different conclusions, we collected ownership data for 207 listed German non-financial firms in 1991, 1992 and 1993. The total number of listed non-financial firms in Germany in 1992 was 510. The main source for our ownership data was Wegweiser durch deutsche Unternehmen published by Bayerische Hypobank, which provides more detailed information on the ownership and equity capital structure of German AGs, both listed and unlisted, than any other source known to us. Unfortunately this source ceased publication in 1994, which explains our choice of time period. We also used Wer gehört zu wem, published by Commerzbank, which covers many more firms than Wegweiser durch deutsche Unternehmen but provides less detail on each. The criteria we used for including a firm in our sample were that it should be possible to obtain definite information about its ownership structure, different classes of shares, voting caps, etc. in each of 1991-3, and that its voting shares should be traded. The main reason why firms were excluded from our sample was that tracing control rights through a pyramid would often lead to a firm that was not a public limited company and for which no ownership information could be found. Faccio and Lang (2002, pages 373-4) adopt the approach of classifying unlisted firms for which ownership data was unavailable as families, and they provide some justification for this in the case of Germany. In their sample of 704 listed financial and non-financial firms, 265 have controlling ultimate owners that are unlisted firms treated as families, so that there is some uncertainty about the ultimate ownership of a large proportion of these firms. We did not follow the Faccio and Lang approach. Instead we excluded firms from our sample if their control chain finished with an unlisted firm for which ownership data was unavailable. This means that our sample has a disproportionately small number of firms owned via a pyramid. We took this approach because our objective is to compare different methods of measuring the control rights of firms, rather than to provide a comprehensive picture of ownership structure. We wanted to be certain that the ownership data on the basis of which our control-rights measures were calculated were accurate, so that the conclusions we reached were not subject to the qualification that they depended on the assumption that unlisted firms with no ownership data were wholly owned by families. We also excluded a small number of firms from our sample because all the voting shares were 
held by a single owner, so that the only shares for which a price was available were non-voting ones. The overall effect of the criteria we used to construct our sample is that it is not representative of all listed German non-financial firms: the firms included were on average much larger than the excluded firms. ${ }^{7}$ However, for our purposes, it is more important to have accurate ownership data than a representative sample.

First-tier owners were classified into seven different types: families (including foundations set up by families), widely-held domestic financial firms, widely-held non-financial firms, public-sector bodies, cooperatives, foreign parent firms, and closely-held domestic firms, i.e., firms with one or more identifiable large owners. Ultimate ownership coincides with first-tier ownership for those firms whose first-tier owners were not closely-held firms. For those first-tier owners that were closely-held domestic firms, we traced control rights back through pyramids until we were able to identify ultimate owners in one of the six other categories used for first-tier owners. Thus the difference between first-tier and ultimate ownership is wholly due to the process of tracing control rights through the control chains associated with those firsttier owners that are closely-held firms.

For each firm, the voting rights of all owners identified in our sources were recorded in each of the three years. When a firm's ownership structure involved a pyramid, the voting rights of all owners of the firms at the different links in the control chain were recorded. The measurement of voting rights took account of all relevant features, such as the existence of non-voting shares, multiple voting shares, and voting caps. We then used these voting rights data to obtain alternative measures of the control rights of the largest and second-largest first-tier and ultimate owners of each firm.

Before presenting these different measures, it is necessary to note some relevant features of German corporate law. All listed German firms are required to have a supervisory board as well as a management board. The latter is responsible for the operation of the firm, and is appointed by the former. In almost all cases,

\footnotetext{
${ }^{7}$ The mean and median values of total assets in 1992 for the 207 firms in our sample were DM $3,889,487,000$ and DM 498,570,400 respectively. We were only able to obtain data for 288 of the 303 excluded firms: the corresponding values for these firms were DM 736,319,700 and DM 157,325,900.
} 
codetermination laws require the supervisory board to be composed of members elected separately by the owners and the employees of the firm. ${ }^{8}$ The procedure for election of the owner representatives involves a simple majority vote at the owners' meeting. An owner with a majority of the voting rights thus has complete control of the owner representatives on the supervisory board. But codetermination means that such an owner does not necessarily have complete control of the management board, and hence of the way in which the firm is run. There are three different forms of codetermination. Under Montan codetermination, which applies to certain coal and steel firms, the supervisory board has equal numbers of owner and employee representatives, together with a neutral member to break ties. A Montan firm also has a labour director on its management board, who (in contrast to the other members of the management board) cannot be appointed if a majority of the employee representatives on the supervisory board vote against the appointment. For firms not subject to Montan codetermination and having 2,000 or more employees, there are equal numbers of owner and employee representatives on the supervisory board. In these firms, the chairman of the supervisory board, who is elected either by a twothirds majority or, if such a majority cannot be achieved, by the shareholder representatives alone, can cast a second vote to break ties. Such firms are also required to have a labour director on the management board, but this director can be appointed even if a majority of the employee representatives on the supervisory board vote against the appointment. Finally, for firms not subject to Montan codetermination and having fewer than 2,000 employees, one third of the supervisory board consists of employee representatives, and there is no requirement for a labour director to be on the management board.

An owner with a majority of the voting rights in a listed firm that is not subject to Montan codetermination and has fewer than 2,000 employees is therefore able to appoint exactly his or her desired management board, and thus effectively has full control of the way in which the firm is run. But an owner with a majority of voting rights in a listed firm that has at least 2,000 employees or is subject to Montan codetermination faces some constraints on his or her ability to appoint the management board. At this stage we simply note the possibility that a given value of

\footnotetext{
${ }^{8}$ Certain types of firm are exempt from the requirement to have employee representatives on the supervisory board, but the firms analysed in this paper all have employee representatives.
} 
voting rights may correspond to different values of control rights (however measured) depending on firm codetermination status. In the next section we take account of this possibility in our empirical comparison of control right measures.

A second relevant feature of German corporate law is that some decisions about the firm's operations, such as mergers, liquidations, and changes in its statutes and equity capital, have to be made by a vote at the owners' general meeting, rather than by the management board, and usually require a 75 per cent majority. Hence complete control of all decisions made at the owners' meeting requires an owner to have more than 75 per cent of the voting rights. Whether this requirement actually means that an owner with, say, 70 per cent of the voting rights does not have complete control of the way in which a firm is run is unclear: it can be argued that the ability to appoint the management board gives an owner complete control provided that the necessity to make decisions requiring a 75 per cent majority can be avoided. We therefore computed two different measures of control rights based on the SSI. In one, possession of a simple majority of voting rights was assumed to give an owner complete control, so that the quota was 50 per cent, while in the other complete control was assumed to require more than three-quarters of the voting rights (the quota was 75 per cent).

Our control-right measures are therefore as follows. One set of measures equates control and voting rights: this applies straightforwardly to first-tier owners (and is henceforth referred to as the FTVR control-right measure), and is adapted to ultimate owners by the use of the WLP (the UTWL control-right measure hereafter). The other set of control-right measures is based on the SSI. The first-tier voting-right data were used to compute SSIs for first-tier owners corresponding to quotas of 50 and 75 per cent. These first-tier measures are true SSIs, and are henceforth referred to as the FTSS50 and FTSS75 control-right measures respectively. When ownership involved pyramids, the control-rights measures were computed by calculating the products of the SSIs at the different links in the control chain. As noted in the previous section, the resulting SSI-based measures of ultimate owners control rights are not true SSIs. They are referred to respectively as UTSS50 and UTSS75 measures depending on whether the quota used in the computation of the SSIs at each tier of the pyramid was 50 or 75 per cent. 
In all but one case, multiple control chains and cross-holdings were incorporated into our measures of ultimate ownership straightforwardly. ${ }^{9}$ The exception is the insurance company Allianz, which in all three years owned the largest proportion of voting rights in both the largest and one of the joint second-largest holders of its voting rights (the insurance company Münchener Rückversicherung and Dresdner Bank respectively). Since Allianz appeared to control itself, it was classified as a widely-held firm. ${ }^{10}$

Table 1 shows the distribution of largest owner control and cash-flow rights for the 621 observations in our sample according to the control-rights measure used to determine ownership. A largest owner was identified for nearly 95 per cent of these observations. Note that there is a considerable amount of overlap between, for example, the FTVR and UTWL measures of control rights. These differ only with respect to the 251 observations for which the process of tracing control through pyramids resulted in the ultimate measures differing from the first-tier ones. ${ }^{11}$ Firsttier and ultimate ownership coincide for the other 370 observations. A similar overlap exists for the FTSS50/UTSS50 and FTSS75/UTSS75 measures.

Depending on the quota, the SSI-based control-rights measures assign complete control to an owner with more than 50 or 75 per cent of the voting rights. Consequently the control rights of largest owners shown in Table 1 are greatest when they are measured using the SSI with a 50 per cent quota and smallest when they are equated with voting rights. The move from first-tier to ultimate ownership measures lowers the largest owner's control rights: these are smaller according to the UTWL measure than according to the FTVR measure, and similarly for the UTSS50 and UTSS75 measures as compared to their first-tier equivalents. However control rights are measured, the typical firm in our sample has a controlling owner: the median value of the largest owner's control rights is at least 50 per cent for all six measures. But the different measures produce different frequency distributions of largest

\footnotetext{
${ }^{9}$ Multiple control chains occur when there is more than one chain of voting rights from firms to their ultimate owners.

${ }^{10}$ La Porta et al. (1999, p. 486) also classify Allianz as widely-held.

${ }^{11}$ There are 243 observations where the largest first-tier owner is a closely-held firm, so that ultimate measures necessarily differ from first-tier ones, and another 8 observations where taking account of the ownership structure of first-tier owners other than the largest leads to differences between ultimate and first-tier measures.
} 
owner's control rights. This is obvious for most comparisons of the distributions in Table 1, but was confirmed formally by testing the significance of the differences using the Kolmogorov-Smirnov (KS hereafter) test. For all possible pairwise comparisons of the distributions of largest owner's control rights, the KS test strongly rejected the null hypothesis of no difference.

Table 1 also shows alternative measures of the largest owner's cash-flow rights. The measure based on first-tier ownership, which is the same however first-tier control rights are measured, differs from first-tier voting rights solely as a result of the existence of classes of shares with different voting and dividend rights. It is the fraction of total dividends paid in a year received by the largest first-tier owner, which was obtained using the proportions of voting and non-voting shares held by this owner, and the dividends paid to voting and non-voting shares. ${ }^{12}$ There are only 75 observations (12.08 per cent) where the largest first-tier owner's voting and cash-flow rights differ, so there are only small differences in the mean and median values and the distributions of these two variables are rather similar (the $p$-value at which the KS test rejects the null hypothesis of no difference is 0.098). There are three different. measures of the largest ultimate owner's cash-flow rights, corresponding to the different measures of ultimate control rights. These cash-flow rights are computed as the product of this owner's cash-flow rights at each tier of a control chain (in some cases more than one control chain linked an ultimate owner to a firm at the bottom of a pyramid). The only reason why these ultimate cash-flow right measures differ is that, for a very small number of firms, different measures of ultimate control rights resulted in different largest owners being identified. The important difference is the one between the largest owner's cash-flow rights measured at the first-tier and ultimate levels, whichever measure of the latter is used. The largest owner's cash-flow rights are smaller when ownership is traced through pyramids. The KS test strongly rejects the null hypotheses of no difference between the first-tier distribution and each of the three ultimate distributions.

\footnotetext{
${ }^{12}$ In Germany non-voting shares typically receive a slightly higher dividend than voting shares, and in 1991-3 payments to shareholders had to take the form of dividends as share repurchases were not allowed.
} 
Table 1: Alternative measures of largest owner's control and cash-flow rights

Panel A shows the distributions of the largest owner's control and cash-flow rights in our sample of firms according to six different measures of control rights. Panel B gives summary statistics for the different measures of the largest owner's control and cash-flow rights.

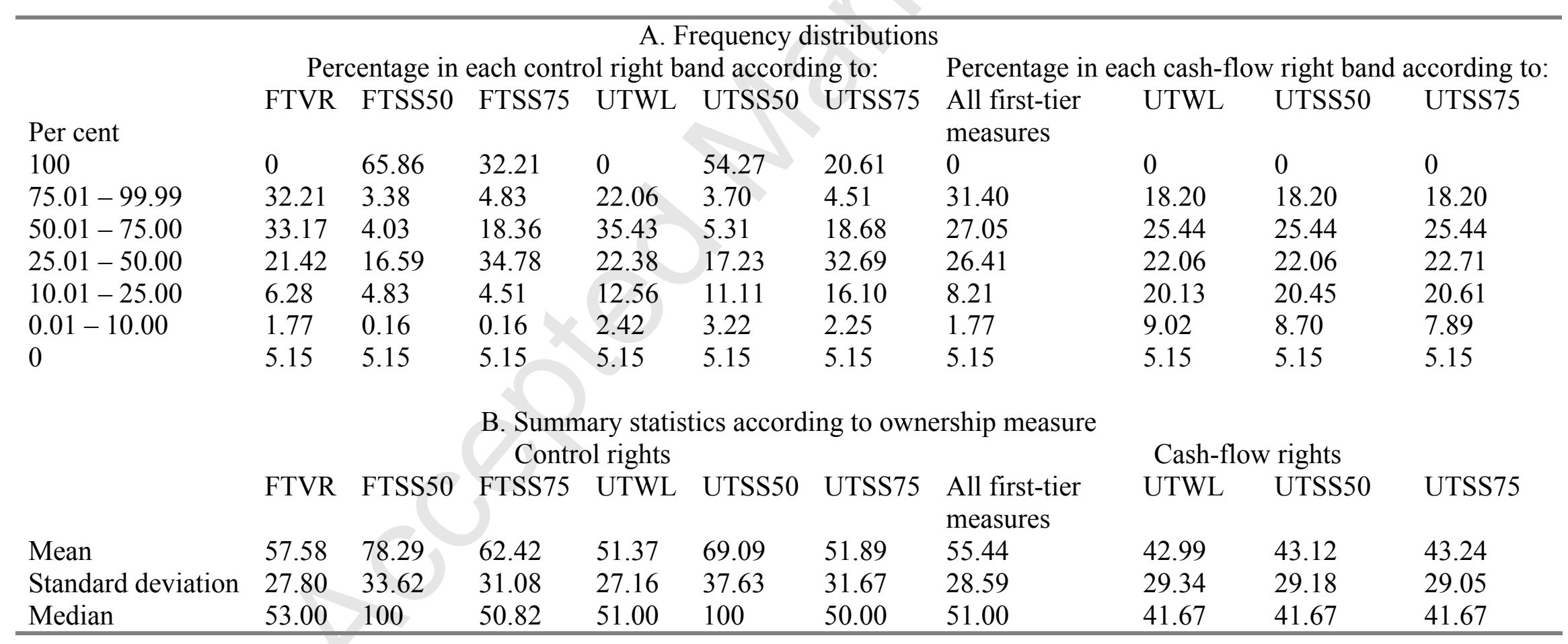


Our results show that the distribution of the largest owner's control rights based on the WLP differs substantially from the distributions obtained using other control rights measures, and hence analyses of largest owner control rights should not be based exclusively on the WLP in the absence of a strong justification for so doing. This means, for example, that the analysis of ownership structure in Faccio and Lang (2002, henceforth FL) must be regarded as tentative. Our sample of listed German firms is smaller than that of FL, and their German data is for 1996, a later period than ours, so some differences between their WLP-based ownership measures and ours are to be expected. But the differences are small. We compared our 1993 UTWL ownership measures (the latest year for which we have data) with FL's ownership figures for the 163 firms that were in both samples. The mean (standard error) of our UTWL measure of the largest owner's control rights is 0.4907 (0.0211), compared to 0.4965 (0.0223) for FL's measure, so there is no significant difference between the two means. The corresponding values for the largest owner's cash-flow rights are $0.4018(0.0229)$ for our measures and $0.4434(0.0244)$ for FL's. The difference between these two means is statistically significant at the 0.05 level, although not large enough to suggest a major difference between our cash-flow measures and those of FL. This conclusion is supported by KS tests. Neither the null hypothesis of no difference between the distributions of the two control rights measures nor that of no difference between the distributions of the two cash-flow rights measures were rejected by the KS test. These comparisons suggest that the differences in control and cash-flow rights implied by alternative measures that we report in Table 1 would also be found in FL's larger sample of listed German firms, and thus justifies our view that their results should be regarded as tentative. ${ }^{13}$

In terms of the conflict of interest between controlling and non-controlling owners, the important question about different ownership measures is how they affect the separation between the largest owner's control and cash-flow rights. Table 2 shows this separation according to the six different control-rights measures. There is very little difference between the largest first-tier owner's control and cash-flow rights if the former are measured by FTVR, but there is a more pronounced difference

\footnotetext{
${ }^{13}$ We are very grateful to Mara Faccio and Larry Lang for allowing us to use their unpublished German data in order to make the comparisons in this paragraph.
} 
Table 2: Alternative measures of difference between largest owner's control and cashflow rights

This table gives distributions and summary statistics for the difference between the largest owner's control and cash-flow rights according to six different measures of control rights.

\begin{tabular}{l|llllll}
\hline & \multicolumn{5}{|c}{ Percentage in each band according to } \\
$\begin{array}{l}\text { Control rights minus } \\
\text { cash-flow rights(per } \\
\text { cent) }\end{array}$ & FTVR & FTSS50 & FTSS75 & UTWL & UTSS50 & UTSS75 \\
$>50$ & 0 & 7.08 & 0.48 & 2.25 & 12.72 & 0.48 \\
$40.01-50.00$ & 0 & 18.84 & 0.64 & 1.29 & 18.36 & 1.77 \\
$30.01-40.00$ & 1.45 & 8.70 & 1.93 & 2.74 & 8.21 & 2.74 \\
$20.01-30.00$ & 4.35 & 12.88 & 12.72 & 10.47 & 11.11 & 12.40 \\
$10.01-20.00$ & 2.42 & 10.14 & 8.86 & 14.81 & 11.92 & 13.04 \\
$0.01-10.00$ & 3.86 & 34.46 & 47.99 & 17.55 & 30.59 & 47.99 \\
0 & 87.92 & 5.31 & 7.73 & 48.95 & 5.15 & 5.48 \\
$<0$ & 0 & 2.58 & 19.65 & 1.93 & 1.93 & 16.10 \\
& & & & & & \\
Mean & 2.14 & 22.84 & 6.98 & 8.38 & 25.97 & 8.65 \\
Standard deviation & 6.86 & 21.27 & 10.95 & 12.72 & 23.30 & 11.14 \\
Median & 0 & 17.00 & 4.19 & 0 & 20.57 & 4.97 \\
\hline
\end{tabular}

if control rights are measured by FTSS75, while if they are measured by FTSS50 this difference is substantial. The KS test strongly rejects the null hypothesis of no difference between these three distributions of control - cash-flow right differences. When control is traced through pyramids to find ultimate owners, the difference between the largest owner's control and cash flow rights increases for all control right measures. However, although the UTWL measure yields more of a control - cashflow rights difference than the FTVR one, and the two distributions are significantly different according to the KS test, there is still no difference between the largest owner's control and cash-flow rights for nearly half the observations when the UTWL measure is used. Both the UTSS50 and UTSS75 control-rights measures yield a distribution of control - cash-flow differences that is significantly different from that based on the UTWL one according to the KS test. However the distribution based on the UTSS50 measure is not significantly different from that generated by the FTSS50 measure, while the distribution based on the UTSS75 measure is significantly different from the one produced by the FTSS75 measure at a $p$-value of 0.063 . Table 2 shows that, for all measures other than FTVR, there are cases in which the 
controlrights of the largest owner are less than this owner's cash-flow rights, particularly when the FTSS75 and UTSS75 measures are used.

Table 3 shows the control rights of the second-largest owner in the five cases where these can be measured straightforwardly. ${ }^{14}$ The proportion of observations in which a second-largest owner was identified varied from 20 per cent (in the FTSS50 case) to 47 per cent (in the UTSS75 case). The control rights of second-largest owners were often rather small, but it is clear that there is a non-trivial number of firms in our sample for which it is possible that the second-largest owner has sufficient control rights to constrain the largest owner. It is therefore important to use measures of control rights that are capable of accommodating this possibility.

Table 3: Alternative measures of second-largest owner's control rights

This table gives distributions and summary statistics for the second-largest owner's control rights according to five different measures of control rights (see text for explanation of why there is no second-largest owner's control rights figure when the WLP is used to measure control rights).

\begin{tabular}{l|lllll}
\hline & \multicolumn{5}{|c}{ Percentage in each control right band according to: } \\
Per cent & FTVR & FTSS50 & FTSS75 & UTSS50 & UTSS75 \\
$25.01-50.00$ & 14.17 & 5.15 & 20.45 & 4.03 & 10.31 \\
$10.01-25.00$ & 13.85 & 7.89 & 11.11 & 9.98 & 17.07 \\
$0.01-10.00$ & 7.73 & 6.92 & 3.54 & 15.62 & 19.97 \\
0 & 64.25 & 80.03 & 64.90 & 70.37 & 52.66 \\
& & & & & \\
Mean $^{\text {a }}$ & 20.75 & 15.93 & 30.23 & 12.36 & 17.56 \\
Standard deviation $^{\mathrm{a}}$ & 9.11 & 11.17 & 16.41 & 10.98 & 14.79 \\
Median $^{\mathrm{a}}$ & 24.00 & 13.09 & 33.30 & 8.75 & 12.07 \\
\hline
\end{tabular}

Notes. (a) These means, standard deviations and medians are calculated for those observations with positive values only.

The evidence from our sample of listed German firms presented in this section shows clearly that the extent of the largest owner's control rights, and the degree of separation between this owner's control and cash-flow rights, varies considerably depending on the way in which control rights are measured. Do these differences

\footnotetext{
${ }^{14}$ As has been noted, it is unclear how to treat the control rights of owners other than the largest using the WLP.
} 
matter? To answer this question, we analyse in the next section whether different measures of control rights, and the consequent different measures of control and cashflow right separation, lead to significantly different conclusions concerning the effects of the divergence between the largest owner's control and cash-flow rights.

\section{The effect of the largest owner's control and cash-flow rights on firm value according to different measures}

\subsection{The procedure}

It is possible in principle to evaluate the extent to which there is a conflict of interest between controlling and non-controlling owners because of a divergence between the former's control and cash-flow rights by regressing firm value on measures of these control and cash-flow rights. This approach is based on the assumption that the effects of the largest owner's control and cash-flow rights are reflected in the share value of firms. The value of a firm's shares will depend on the valuation of marginal shareholders. Suppose that these marginal shareholders are noncontrolling owners who correctly anticipate the way in which the largest owner's behaviour depends on his or her control and cash-flow rights. Other things equal, increases in the control rights of the largest owner have theoretically ambiguous effects on the value of shares. They increase the ability of the largest owner to obtain private benefits of control at the expense of non-controlling owners, and this effect will lower the value of the firm's shares. But they also increase the ability of the largest owner to limit agency costs by monitoring the management of the firm, and this effect will raise the value of the firm's shares. Which of these effects dominates is an empirical matter that is given by the sign of the estimated coefficient of the largest owner's control rights in the regression equation. ${ }^{15}$ However, increases in the cashflow rights of the largest owner, other things equal, unambiguously strengthen the incentives for this owner to ensure that firm value is maximised, thus increasing firm value. The estimated coefficient of the largest owner's cash-flow rights in the regression equation is thus expected to be positive.

\footnotetext{
${ }^{15}$ We thank an anonymous referee for emphasising this point. See also Edwards and Weichenrieder (2004).
} 
A number of studies have used this approach to investigate the effects of the largest owner's control and cash-flow rights on non-controlling owners. Claessens et al. (2002) and Barontini and Caprio (2005) use the WLP to measure the largest ultimate owner's control and cash-flow rights and, using data for East Asian and Continental European countries respectively, find evidence that increases in the difference between control and cash-flow rights lower firm value. Edwards and Weichenrieder (2004) measure control rights as the proportion of votes actually exercised at shareholders' meetings and find, in a cross-section of German firms, that increases in the largest owner's control rights decrease firm value while increases in the largest owner's cash-flow rights increase firm value. ${ }^{16}$

In order to establish whether different measures of control and cash-flow rights lead to significantly different conclusions about the conflict of interest between controlling and non-controlling owners, we estimate regression models relating firm value to the largest owner's control and cash-flow rights, together with several other variables. We compare the estimated effects of the largest owner's control and cashflow rights according to the particular measures of these rights used in the regressions, and show that different measures lead to different conclusions about the effects of these variables.

The basic regression model that we estimate is one with firm-specific effects as follows:

$$
\begin{aligned}
& \ln M T B_{i t}=\beta_{0}+\beta_{1} C R 1_{i t}+\beta_{2} C R 1_{i t} \times C O D E T_{i t}+\beta_{3} C F 1_{i t}+\beta_{4} C F 1_{i t} \times C O D E T_{i t} \\
& +\beta_{5} C R 2_{i t}+\gamma \cdot X_{i t}+u_{i}+v_{t}+\varepsilon_{i t}
\end{aligned}
$$

In this equation $i$ and $t$ are firm and year subscripts respectively. MTB is the ratio of market to book value of equity capital measured at the end of the year. $C R 1$ and $C F 1$ are measures of the largest owner's control and cash-flow rights respectively, and $C R 2$ is a measure of the second-largest owner's control rights. CODET is a dummy variable that takes the value one if more than one-third of a firm's supervisory board consists of employee representatives and is zero otherwise. $X$ is a vector of other

\footnotetext{
${ }^{16}$ In a recent study, Chirinko and Elston (2006) consider the special role of bank ownership on the profitability of German listed firms. They also look at whether bank influence may substitute for other instruments of corporate control, but do not look at the different effects of control and cash-flow rights.
} 
explanatory variables, $u_{i}$ is a firm effect, $v_{t}$ is a time effect, and $\varepsilon_{i t}$ is a idiosyncratic error term.

The expected sign of the coefficient $\beta_{1}$ is ambiguous, for the reasons that have been discussed, while $\beta_{3}$ is expected to be positive. The expected sign of $\beta_{5}$ is also ambiguous: increases in the control rights of the second-largest owner may limit the largest owner's pursuit of private benefits of control, thus raising firm value, or lead to collusion so that the two largest owners jointly extract more such private benefits, thus lowering firm value. Faccio et al. (2001) provide some evidence that the presence of other large owners restrains the largest owner's expropriation of minority owners in Europe, but accentuates it in East Asia. Gugler and Yurtoglu (2003) find evidence for Germany that the presence of a second large owner limits the private benefits of control obtained by the largest owner.

The terms that interact ownership measures with the codetermination dummy are included to allow for the possibility that stronger employee representation on a firm's supervisory board affects the relationship between firm value and the largest owner's control and cash-flow rights. As discussed in the previous section, it is possible, for example, that a given measure of control rights computed from the largest owner's voting rights corresponds to greater effective control if only one-third of the supervisory board is comprised of employee representatives, and hence the effect of a given value of control rights on firm value may vary between firms with different codetermination statuses. Our codetermination dummy variable does not distinguish between firms subject to Montan codetermination and firms with 2,000 or more employees. Only three of the 207 firms in our sample were subject to Montan codetermination, and we therefore combined these firms with those non-Montan firms having at least 2,000 employees to create the codetermination dummy. We do not include the codetermination dummy as a separate regressor, because we estimate the model using the fixed-effects (within) estimator and there is hardly any within variation in this variable. Only three of the firms in our sample had a change in the value of the codetermination dummy during the three years 1991-3.

The $X$ vector in our regression model consists of a firm size variable, dummy variables for 1992 and 1993 to control for time effects on MTB, two variables to 
control for the influence of growth prospects on firm valuation, and three variables to control for other effects on the relationship between the market and book values of equity. We measure firm size by the logarithm of total assets ( $\ln A S S E T S)$. Our two growth prospects variables are the growth of sales in the previous year (SALESGR) and the growth of the book value of equity capital in the previous year (CAPGR): the justification for the latter is that increases in the book value of equity capital indicate investment to take advantage of growth opportunities. Our three other control variables were the following. Total debt as a proportion of total assets $(D E B T)$ was included as a regressor because debt is favourably treated by the tax system and may exert favourable effects on managerial effort and the consumption of private benefits of control (Jensen and Meckling 1976, Jensen 1986). Pension provisions as a proportion of total assets (PENSION) and other provisions as a proportion of total assets (OTHER) were included as regressors because of possible problems related to the use of the book value of equity in the denominator of our dependent variable. In Germany, both sets of liabilities may benefit the owners of a firm: pension provisions are a cheap source of investment finance, while other provisions are regarded as being a valuable vehicle for creative accounting and income smoothing. ${ }^{17}$

A critical question to consider is whether the estimates of the coefficients of the ownership variables in our regression model can be given a causal interpretation. As argued by Demsetz and Lehn (1985), Himmelberg et al. (1999), and Demsetz and Villalonga (2001), firm ownership structure may not be exogenous but rather endogenously determined by a number of observed and unobserved firm characteristics, with the result that omitted variable bias affects the estimated coefficients of the ownership variables. If the regression can be estimated on panel data, then the fixed effects model permits consistent estimates under the assumption that there is unobserved firm heterogeneity which may be correlated with the regressors. This is the estimation method we adopt. Under the assumption that the effect of the unobserved determinants of ownership on firm value is constant over time once the effects of the observeable regressors are taken into account, we can give a causal interpretation to the estimated coefficients of the ownership regressors even though ownership is endogenous. Since we have only three years of data on each of

\footnotetext{
${ }^{17}$ The issues involved here are discussed in Edwards and Weichenrieder (2004).
} 
the firms in our sample, the assumption that the unobserved heterogeneity is constant over time appears reasonable.

There may be correlation between the ownership regressors and the idiosyncratic error term in our regression model due to either reverse causation or measurement error. The former reflects possible effects of firm value on ownership structure: for example, the largest owner may possess inside information and hence change her stake in the firm if it is over- or undervalued. The latter reflects the possibility that some, if not all, our ownership variables measure true control and cash-flow rights with an error that is not time-invariant. For the moment, we note that our use of the fixed effects estimator does not remove all possible concerns about endogeneity of the ownership variables, but maintain the hypothesis that there is no correlation between the ownership regressors and the idiosyncratic error. We return to this assumption at the end of the section.

\subsection{Data and estimates of basic model}

The data necessary to construct the various non-ownership variables in the regression model were collected from the Hoppenstedt Aktienfuhrer and the Hypobank Wegweiser durch deutsche Unternehmen. Summary statistics for all variables used in the regression analysis are given in Table 4. Note that the ownership variables are expressed as fractions rather than percentages in this table. This table makes clear that the reason for specifying the dependent variable in our regression model as the logarithm of MTB is that the distribution of MTB is highly dispersed and positively skewed. The decomposition of the overall standard deviation of the variables in Table 4 into their between and within standard deviations shows that for most of them variability is much greater between firms than it is over time for given firms. Only the two growth prospect variables have a greater within than between standard deviation.

The fact that there is much less within than between variation for most of the variables in Table 4 means that it would be desirable to estimate our regression model by the random-effects estimator, which gives a weighted average of between and 
Table 4: Summary statistics for regression variables

This table gives summary statistics for the variables used in the regression analysis. See Table A1 for definitions of these variables.

\begin{tabular}{l|llllll}
\hline Variable & Overall & Overall & Between & Within & Overall & Overall \\
& mean & st. dev. & st. dev. & st. dev. & max & min \\
$M T B$ & 3.2377 & 3.9430 & 3.8091 & 1.0415 & 38.5795 & 0.4034 \\
$\ln M T B$ & 0.8828 & 0.6768 & 0.6427 & 0.2153 & 3.6527 & -0.9078 \\
$C R 1$ (FTVR) & 0.5758 & 0.2780 & 0.2740 & 0.0494 & 0.998 & 0 \\
$C R 1$ (FTSS50) & 0.7829 & 0.3362 & 0.3298 & 0.0676 & 1 & 0 \\
$C R 1$ (FTSS75) & 0.6242 & 0.3108 & 0.3058 & 0.0584 & 1 & 0 \\
$C R 1$ (UTWL) & 0.5137 & 0.2716 & 0.2645 & 0.0636 & 0.998 & 0 \\
$C R 1$ (UTSS50) & 0.6909 & 0.3763 & 0.3611 & 0.1079 & 1 & 0 \\
$C R 1$ (UTSS75) & 0.5189 & 0.3167 & 0.3100 & 0.0670 & 1 & 0 \\
$C F 1$ & 0.5544 & 0.2859 & 0.2821 & 0.0492 & 0.998 & 0 \\
$C F 1$ (UTWL) & 0.4299 & 0.2934 & 0.2858 & 0.0680 & 0.998 & 0 \\
$C F 1$ (UTSS50) & 0.4312 & 0.2918 & 0.2835 & 0.0710 & 0.998 & 0 \\
$C F 1$ (UTSS75) & 0.4324 & 0.2905 & 0.2839 & 0.0636 & 0.998 & 0 \\
$C R 2$ (FTVR) & 0.0742 & 0.1134 & 0.1099 & 0.0287 & 0.4618 & 0 \\
$C R 2$ (FTSS50) & 0.0318 & 0.0809 & 0.0782 & 0.0210 & 0.3333 & 0 \\
$C R 2$ (FTSS75) & 0.1061 & 0.1740 & 0.1688 & 0.0435 & 0.5 & 0 \\
$C R 2$ (UTSS50) & 0.0366 & 0.0821 & 0.0792 & 0.0223 & 0.5 & 0 \\
$C R 2$ (UTSS75) & 0.0831 & 0.1343 & 0.1308 & 0.0314 & 0.5 & 0 \\
$C O D E T$ & 0.4863 & 0.5002 & 0.4978 & 0.0568 & 1 & 0 \\
$\ln A S S E T S S^{b}$ & 13.1980 & 1.9919 & 1.9900 & 0.1426 & 18.3256 & 7.9862 \\
SALESGR & 0.0817 & 0.3744 & 0.2154 & 0.3065 & 7.8000 & -0.9683 \\
$C A P G R$ & 0.0549 & 0.2811 & 0.1658 & 0.2273 & 2.7694 & -0.8196 \\
$D E B T$ & 0.4322 & 0.1734 & 0.1671 & 0.0470 & 0.9063 & 0.0469 \\
$P E N S I O N$ & 0.1171 & 0.0811 & 0.0798 & 0.0149 & 0.4839 & 0 \\
OTHER & 0.1466 & 0.0943 & 0.0904 & 0.0272 & 0.7058 & 0.0071 \\
\hline
\end{tabular}

Notes. (a) $C F 1$ is the same for all first-tier measures. (b) $\ln A S S E T S$ is the logarithm of ASSETS measured in thousand DM.

within estimates, rather than by the fixed-effects estimator, which only uses within variation. However, unlike the fixed-effects estimator, the random-effects estimator is inconsistent if the unobserved firm-specific effects $u_{i}$ are correlated with the regressors. The Hausman test always rejects the null hypothesis of no difference between the fixed- and random-effects estimates of our model, and so we only use the fixed-effects estimator.

The basic regression model was estimated using each of the six different ownership measures. The null hypothesis that both $\beta_{2}$ and $\beta_{4}$ were zero was not rejected for five of the six models. To save space, Table 5 therefore shows estimates of the different models in which, for all except the UTSS75 model, the restriction that 
the coefficients of $C R 1$ and $C F 1$ do not depend on the codetermination status of firms is imposed.

There is no evidence that $C R 2$ has a significant effect on firm value. For all models in which this is an explanatory variable, the estimated coefficient is negative but not significantly different from zero, and in all cases the implied elasticity of $M T B$ with respect to $C R 2$ at the sample mean is very small indeed.

In all three first-tier models shown in Table 5, the estimated coefficient of $C F 1$ is positive, and thus consistent with the basic hypothesis about the effect of increases in the largest owner's cash-flow rights on share value, while the estimated coefficient of $C R 1$ is negative, implying that the overall effect of increases in the largest owner's cash-flow rights is to harm non-controlling owners and so lower share value. Although the statistical significance of these coefficients in the FTSS50 model is questionable, all three first-tier models lead to the same general conclusion about the effects of the largest owner's control and cash-flow rights on share value.

This is not the case for the three ultimate ownership models in Table 5. The results of the UTSS50 model are consistent with those of the three first-tier models, but those of the other two ultimate ownership models are not. In the UTWL model, the point estimates of the $C R 1$ and $C F 1$ variables are very close to zero, and certainly not statistically significantly different from zero, so that this model yields the conclusion that the largest owner's control and cash-flow rights have no effects on share value. In the UTSS75 model, although the statistical significance of the coefficient estimates is questionable, the effects of the $C R 1$ and $C F 1$ variables depend on firm codetermination status. According to this model, in firms where employees have weak codetermination rights, increases in $C F 1$ lower share value, contrary to the basic hypothesis, while increases in $C R 1$ raise it. However, in firms where employees have strong codetermination rights, the general conclusion about the effects of the largest owner's control and cash-flow rights on share value is consistent with that of the first-tier and UTSS50 models. 
Table 5: Estimates of basic model with different ownership variables

This table gives fixed-effects estimates of regression models explaining the natural logarithm of a firm's ratio of market to book value of equity capital in terms of ownership variables and several other control variables. The regressions differ in terms of how the control rights of the largest and second-largest owner's control rights were measured.

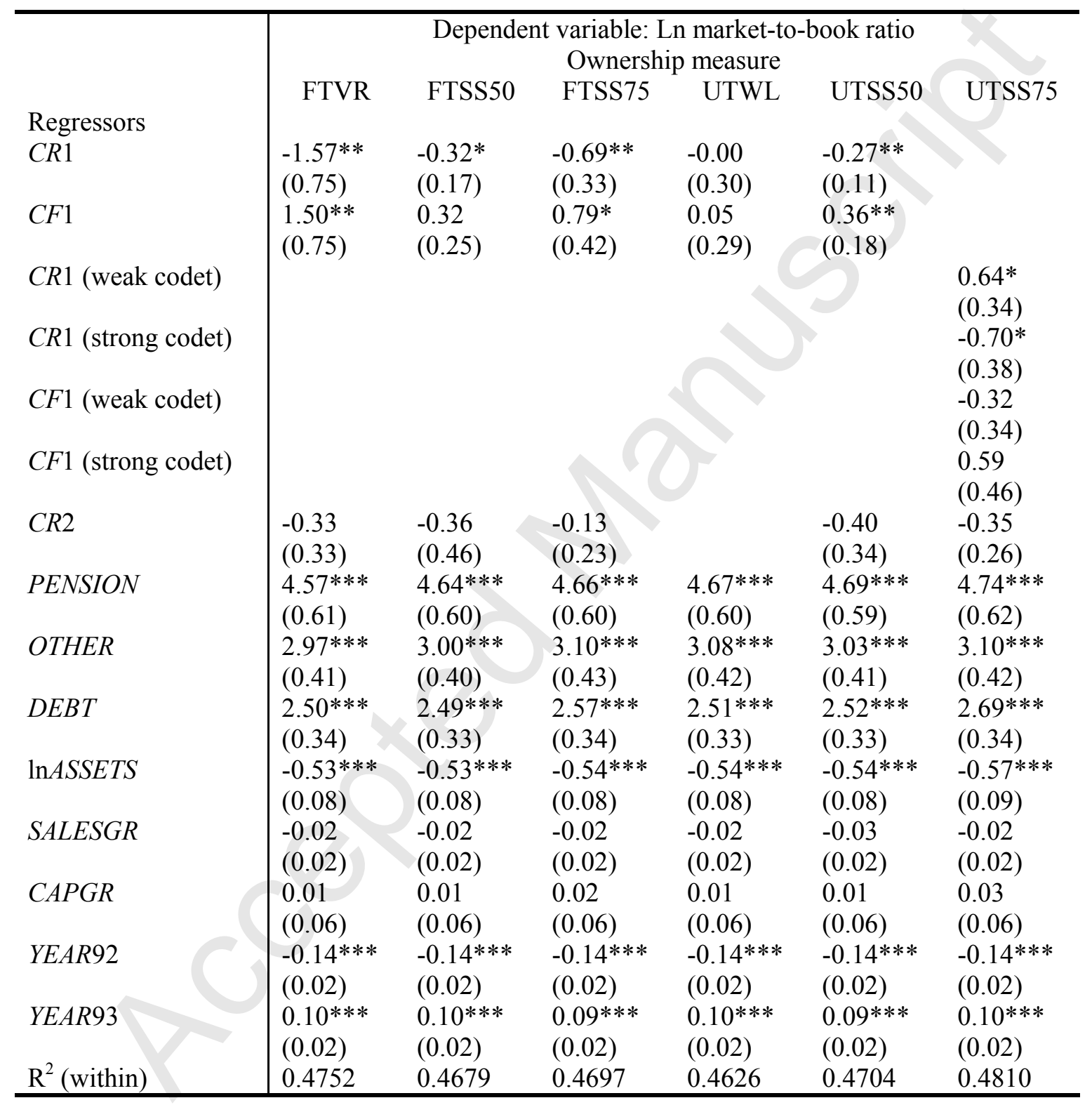

Notes: (a) Cluster-robust standard errors in parentheses (clustering on firms). (b) *,** and *** indicate significance at the $0.10,0.05$ and 0.01 levels respectively. (c) All regressions are estimated using a total of 621 observations for 207 firms.

The results in Table 5 show clearly that different ownership measures yield different conclusions about the effects of the largest owner's control and cash-flow 
rights on share value when used on our sample of listed German firms. In particular, when the widely-used WLP method of measuring control rights is employed on our data, it gives results that differ from most other models by implying that neither the control rights nor the cash-flow rights of the largest owner have any effect on share value.

\section{$\underline{4.3 \text { Estimates of an expanded model }}$}

A question raised by the results in Table 5 is why the estimated effects of these variables differ between the FTVR and FTSS75 models and the UTWL and UTSS75 models. As was noted in section 3, there is a great deal of overlap between the values of the ownership variables in the corresponding first-tier and ultimate ownership models. These differ only for the 251 observations in which control was exerted via a pyramid. Hence the answer to the question just raised must depend in part on the difference between the first-tier and ultimate measures of control and cashflow rights for these observations. Table 6 therefore reports the results of estimating regression models in which the effects of $C R 1$ and $C F 1$ were allowed to differ according to whether the observations on these variables referred to firms that were or were not owned via a pyramid. The coefficients of the $C R 1$ and $C F 1$ non-pyramid variables give the estimated effect for firms not owned via a pyramid, while the coefficients for the corresponding pyramid variables give the estimated effect for firms owned via a pyramid. It is useful to conduct this exercise for all six ownership models, because if ownership is correctly measured at the ultimate level then the largest owner's control and cash-flow rights are measured inaccurately for 251 observations in the first-tier models. The null hypothesis that there was no difference between the estimated coefficients of the pyramid and non-pyramid $C R 1$ and $C F 1$ variables was not rejected at conventional levels for the FTSS50, FTSS75 and UTSS50 models in Table $6 .{ }^{18}$ Thus for two of the three first-tier models there is no evidence that the largest owner's control and cash-flow rights are inaccurately measured because control is not traced through pyramids to ultimate owners in such

\footnotetext{
${ }^{18}$ The $p$-values for this test were $0.41,0.59$ and 0.58 respectively.
} 
Table 6: Estimates of expanded model with different ownership variables

This table gives fixed-effects estimates of regression models which differ from those shown in Table 5 by allowing the estimated coefficients of the largest owner's control and cash-flow rights to differ according to whether this owner exerted control directly or via a pyramid.

\begin{tabular}{|c|c|c|c|c|c|c|}
\hline & \multicolumn{6}{|c|}{ Dependent variable: Ln market-to-book ratio } \\
\hline & FTVR & FTSS50 & FTSS75 & UTWL & UTSS50 & UTSS75 \\
\hline Ownership regressors & & & & & & \\
\hline$C R 1$ non-pyramid & $\begin{array}{l}-1.56^{* *} \\
(0.75)\end{array}$ & $\begin{array}{l}-0.37^{*} \\
(0.21)\end{array}$ & $\begin{array}{l}-0.69^{*} \\
(0.36)\end{array}$ & $\begin{array}{l}-1.54 * * \\
(0.69)\end{array}$ & $\begin{array}{l}-0.35^{*} \\
(0.19)\end{array}$ & \\
\hline$C R 1$ pyramid & $\begin{array}{l}5.47 * * * \\
(1.74)\end{array}$ & $\begin{array}{l}-0.17 \\
(0.18)\end{array}$ & $\begin{array}{l}-0.56 \\
(0.38)\end{array}$ & $\begin{array}{l}0.32 \\
(0.29)\end{array}$ & $\begin{array}{l}-0.18 \\
(0.12)\end{array}$ & \\
\hline$C F 1$ non-pyramid & $\begin{array}{l}1.53 * * \\
(0.74)\end{array}$ & $\begin{array}{l}0.43 \\
(0.32)\end{array}$ & $\begin{array}{l}0.81^{*} \\
(0.44)\end{array}$ & $\begin{array}{l}1.66^{* *} \\
(0.69)\end{array}$ & $\begin{array}{l}0.49^{*} \\
(0.29)\end{array}$ & \\
\hline$C F 1$ pyramid & $\begin{array}{l}-5.62 * * * \\
(1.81)\end{array}$ & $\begin{array}{l}0.04 \\
(0.22)\end{array}$ & $\begin{array}{l}0.57 \\
(0.43)\end{array}$ & $\begin{array}{l}-0.37 \\
(0.30)\end{array}$ & $\begin{array}{l}0.18 \\
(0.19)\end{array}$ & \\
\hline$C R 1$ (weak codet) & & & & & & $\begin{array}{l}0.63^{*} \\
(0.35)\end{array}$ \\
\hline $\begin{array}{l}C R 1 \text { non-pyramid } \\
\text { (strong codet) }\end{array}$ & & & & & & $\begin{array}{l}-0.98^{*} \\
(0.52)\end{array}$ \\
\hline $\begin{array}{l}\text { CR1 pyramid } \\
\text { (strong codet) }\end{array}$ & & & & & & $\begin{array}{l}-0.09 \\
(0.31)\end{array}$ \\
\hline$C F 1$ (weak codet) & & & & & & $\begin{array}{l}-0.32 \\
(0.92)\end{array}$ \\
\hline $\begin{array}{l}C F 1 \text { non-pyramid } \\
\text { (strong codet) }\end{array}$ & & & & & & $\begin{array}{l}0.93 * \\
(0.55)\end{array}$ \\
\hline $\begin{array}{l}C F 1 \text { pyramid } \\
\text { (strong codet) }\end{array}$ & & & & & & $\begin{array}{l}-0.50 \\
(0.37)\end{array}$ \\
\hline$C R 2$ & $\begin{array}{l}-0.33 \\
(0.31)\end{array}$ & $\begin{array}{l}-0.44 \\
(0.46)\end{array}$ & $\begin{array}{l}-0.12 \\
(0.24)\end{array}$ & & $\begin{array}{l}-0.37 \\
(0.35)\end{array}$ & $\begin{array}{l}-0.38 \\
(0.25)\end{array}$ \\
\hline $\mathrm{R}^{2}$ (within) & 0.4769 & 0.4699 & 0.4708 & 0.4795 & 0.4716 & 0.4763 \\
\hline
\end{tabular}

Notes: (a) All regressions also included the additional explanatory variables shown in Table 5, the coefficients of which are not reported. (b) Cluster-robust standard errors in parentheses (clustering on firms). (c) $*, * *$ and $* * *$ indicate significance at the $0.10,0.05$ and 0.01 levels respectively. (d) All regressions are estimated using a total of 621 observations for 207 firms.

models. However, there were statistically significant differences between these coefficients in the FTVR, UTWL and UTSS75 models.

It is unclear how to interpret these differences in the FTVR model, because the $C R 1$ and $C F 1$ pyramid variables in it hardly vary. There are only two firms owned via a pyramid in the sample for which the within variation in first-tier voting rights differs from that in first-tier cash-flow rights. Consequently the $C R 1$ and $C F 1$ pyramid 
variables in this model are very highly collinear. This is a good illustration of the general problem with the FTVR model: there may be little measured separation between control and cash-flow rights when the only source of such separation is the existence of shares with different voting and dividend rights. It is therefore difficult to place much weight on the differences between the pyramid and non-pyramid variables in the FTVR model, since the estimated effects of the former are driven by a total of six observations on two firms.

Much more weight can be placed on the differences between the pyramid and non-pyramid variables in the UTWL and UTSS75 models, since these are not driven by just a small number of observations. In the UTWL model, the coefficients of the non-pyramid variables are significant at the 0.05 level and are similar to those of the $C R 1$ and $C F 1$ variables in the FTVR model. However, the estimated coefficients of the pyramid variables have different signs from those of the non-pyramid variables and are not significant at the 0.05 level. When the WLP is used to measure ultimate owners' control rights, it results in estimated coefficients of $C R 1$ and $C F 1$ for ultimate owners who exert control via a pyramid that are very different to those obtained for ultimate owners who do not exert control via a pyramid. Hence if no distinction is made between the two types of ultimate owner (as in Table 5), the UTWL model shows absolutely no effect of the largest owner's control and cash-flow rights. These results suggest that, for our sample of firms, the WLP does not provide a satisfactory basis on which to measure the control and cash-flow rights of owners who exert control via a pyramid. Conditional on voting rights measuring control rights correctly, the coefficients of the $C R 1$ and $C F 1$ non-pyramid variables in the UTWL model give estimates of the effect of the largest owner's control and cash-flow rights: the question of how to measure control rights exerted via a pyramid does not arise in this case. However, the coefficients of the $C R 1$ and $C F 1$ pyramid variables give estimates of the effect of the largest owner's control and cash-flow rights conditional both on voting rights measuring control rights correctly and on the WLP being the correct basis on which to measure control exerted through a pyramid, since the question of how to measure control rights exerted via a pyramid has to be addressed in this case. If the effects of the largest owner's control and cash-flow rights on share value differ according to whether they are or are not exerted via a pyramid, as they do according to the UTWL model in Table 6, one of two conclusions can be drawn. Either the 
control rights exerted through a pyramid are measured incorrectly or there are reasons why the effect of control rights on share value differ according to whether they are exerted directly or via a pyramid. The literature on pyramids has not, to the best of our knowledge, suggested that there is any basis for the latter conclusion. Hence the appropriate conclusion appears to be that the WLP is an unsatisfactory basis on which to measure control rights exerted via a pyramid.

The results for the UTSS75 model in Table 6 incorporate the restriction (which has $p$-value 0.52 ) that the effects of the largest owner in firms where employees have weak codetermination rights are the same for pyramid and nonpyramid observations. The estimated effects of $C R 1$ and $C F 1$ for these firms are different from those in the FTSS75 model but virtually identical to those shown for the UTSS75 model in Table 5: in particular, the sign of the $C F 1$ variable conflicts with the basic hypothesis, although it is not statistically significant. For firms in which employees have strong codetermination rights, the estimated effects of $C R 1$ and $C F 1$ have the same sign as those in the FTSS75 model and are significant at the 0.10 level in the case of non-pyramid observations, but this is not so in the case of pyramid observations. It is not obvious why the move from the FTSS75 to the UTSS75 model produces these changes in the estimated effects of $C R 1$ and $C F 1$, but these results also suggest that, for our sample, the UTSS75 ownership measure is unsatisfactory.

\section{$\underline{4.4 \text { A comparison of different estimates of largest owner control and cash-flow rights }}$}

The results in Tables 5 and 6 are broadly consistent with the hypothesis that share value is influenced by the difference between the largest owner's control and cash-flow rights rather than by these two components separately. We therefore tested whether this restriction could be imposed on the FTSS50, FTSS75 and UTSS50 models in Table 5 (recall that the results in Table 6 provided no evidence that there was any difference between the estimated coefficients of the pyramid and nonpyramid $C R 1$ and $C F 1$ variables in these models). This restriction was not rejected for any of the three models: the $p$-values were $0.99,0.64$ and 0.46 respectively. We also tested whether this restriction could be imposed on the FTVR, UTWL and UTSS75 models in Table 6. The restriction was not rejected for the FTVR and UTWL models 
(the $p$-values were 0.39 and 0.30 respectively), but it was rejected for the UTSS75 model.

Table 7: Estimates of restricted model with different ownership variables

This table gives fixed-effects estimates of regression models which incorporate the restriction that share value is affected by the difference between the largest owner's control and cash-flow rights (see text for explanation of why no such model was estimated using the UTSS75 ownership measure).

\begin{tabular}{|c|c|c|c|c|c|}
\hline \multirow{3}{*}{$\begin{array}{l}\text { Ownership regressors } \\
C R 1-C F 1\end{array}$} & \multicolumn{5}{|c|}{$\begin{array}{c}\text { Dependent variable: Ln market-to-book ratio } \\
\text { Ownership measure }\end{array}$} \\
\hline & FTVR & FTSS50 & FTSS75 & UTWL & UTSS50 \\
\hline & - & $\begin{array}{l}-0.32 * \\
(0.17)\end{array}$ & $\begin{array}{l}-0.69 * * \\
(0.35)\end{array}$ & & $\begin{array}{l}-0.26^{* *} \\
(0.11)\end{array}$ \\
\hline$C R 1-C F 1$ non-pyramid & $\begin{array}{l}-1.55^{* *} \\
(0.73)\end{array}$ & - & - & $\begin{array}{l}-1.56^{* *} \\
(0.72)\end{array}$ & - \\
\hline$C R 1-C F 1$ pyramid & $\begin{array}{l}5.35^{* * *} \\
(1.68)\end{array}$ & - & & $\begin{array}{l}0.25 \\
(0.27)\end{array}$ & - \\
\hline$C R 2$ & $\begin{array}{l}-0.27 \\
(0.23)\end{array}$ & $\begin{array}{l}-0.36 \\
(0.35)\end{array}$ & $\begin{array}{l}-0.18 \\
(0.20)\end{array}$ & $\begin{array}{l}- \\
-\end{array}$ & $\begin{array}{l}-0.45 \\
(0.34)\end{array}$ \\
\hline $\mathrm{R}^{2}$ (within) & 0.4753 & 0.4679 & 0.4693 & 0.4763 & 0.4695 \\
\hline
\end{tabular}

Notes: (a) All regressions also included the additional explanatory variables shown in Table 5, the coefficients of which are not reported. (b) Cluster-robust standard errors in parentheses (clustering on firms). (c) *,** and *** indicate significance at the $0.10,0.05$ and 0.01 levels respectively. (d) All regressions are estimated using a total of 621 observations for 207 firms.

Table 7 shows the estimates obtained when this restriction was imposed on all models for which it was not rejected. In the FTSS50, FTSS75 and UTSS50 models, an increase in the difference between the largest owner's control and cash-flow rights has a negative effect on the logarithm of $M T B$, which is statistically significant (the $p$ value in the FTSS50 model is 0.066). In the FTVR and UTWL models, an increase in the difference between the largest owner's control and cash-flow rights also has a negative and statistically significant effect on the logarithm of MTB provided that these rights are measured for firms that are not owned via a pyramid. The point estimates of the two CR1-CF1 non-pyramid variables in the FTVR and UTWL models are almost identical. But an increase in the difference between the largest owner's control and cash-flow rights in these two models does not have a significant negative effect on the logarithm of MTB when these rights are measured for firms owned via a pyramid. As noted in the previous subsection, the estimated coefficient of 
the $C R 1-C F 1$ pyramid variable in the FTVR model is driven by six observations on two firms, so more attention should be paid to the estimated effect of the $C R 1-C F 1$ pyramid variable in the UTWL model. This is positive but not significantly different from zero. As argued in the previous subsection, this suggests that the WLP is not a satisfactory basis upon which to measure the control rights exerted by largest owners via pyramids.

When we estimate the FTSS50, FTSS75 and UTSS50 models on our sample of German listed firms, we find evidence that share value depends negatively on the difference between the largest owner's control and cash-flow rights, irrespective of whether control is exerted via pyramids or the firm's codetermination status. When we estimate the FTVR and UTWL models, we find evidence that share value depends negatively on the difference between the largest owner's control and cash-flow rights irrespective of the firm's codetermination status, provided that attention is restricted to firms in which ownership is not exerted via a pyramid. Thus, with appropriate caveats about the FTVR and UTWL models, five of the six ownership models give qualitatively similar results: share value is affected by the difference between the largest owner's control and cash-flow rights, and the influence of this difference does not depend on firm codetermination status. The UTSS75 model, however, gives very different qualitative results. We therefore focus on the five models that give qualitatively similar results in the remainder of our discussion.

Do the estimates in Table 7 imply quantitatively similar effects of differences in the largest owner's control and cash-flow rights on firm value? To answer this question, consider the effect on MTB of (for the FTSS50, FTSS75 and UTSS50 models) making the sample mean value of $C R 1$ equal to the sample mean value of $C F 1$ or (for the FTVR and UTWL models) making the sample mean value of $C R 1$ non-pyramid equal to the sample mean value of $C F 1$ non-pyramid. Expressed as a percentage of the sample mean value of MTB, the estimated increase in MTB resulting from aligning the largest owner's control and cash-flow rights in this way was 5.20 per cent according to the FTVR model, 7.59 per cent according to the FTSS50 model, 4.93 per cent according to the FTSS75 model, 5.23 per cent according to the UTWL model and 6.99 per cent according to the UTSS model. All these estimated percentage increases in $M T B$ are statistically significant at conventional levels, although the 
differences between them are not. In absolute terms, the implied increase in average share value if the sample mean value of $C R 1 / C R 1$ pyramid is set equal to the sample mean value of $C F 1 / C F 1$ pyramid varies from DM161,600 (FTSS75 model) to DM248,500 (FTSS50 model). ${ }^{19}$ Thus the different models yield estimates of the increase in share value from aligning the largest owner's control and cash-flow rights that are not insignificantly different in economic terms.

We now return to the possibility that the ownership variables are correlated with the idiosyncratic error in the regression equation. If one of the five models in Table 7 is based on correctly-measured ownership variables, then the ownership variables in the other four models contain measurement errors. If the measurement errors are time-varying, then the estimated coefficients of these ownership variables will be biased and inconsistent. Another reason for considering possible correlation between ownership variables and the idiosyncratic error is simultaneity between firm value and ownership. In order to test this possibility, it is necessary to find instrumental variables that will permit consistent estimates which can be compared with the possibly inconsistent estimates in Table 7. We excluded the FTVR model from these tests because, as has been noted, the estimated coefficient of the $C R 1-C F 1$ pyramid variable in the FTVR model is driven by just six observations on two firms. We used as instruments for the ownership variables in each model in Table 7 except the FTVR one some of the ownership variables from the other models. In each case, the Sargan-Hansen overidentification test does not reject the null hypothesis that the instruments are valid. The (cluster-robust) F-statistics for whether the coefficients of all the instruments are zero in the first-stage regressions for $C R 1-C F 1$ and $C R 2$ respectively in the FTSS50, FTSS75 and UTSS50 models are as follows: FTSS50 10.50 and 3.48, FTSS75 186.90 and 61.20, UTSS50 98.47 and 2.78. The (clusterrobust) F-statistics for whether the coefficients of all the instruments are zero in the first-stage regressions for $C R 1-C F 1$ non-pyramid and $C R 1-C F 1$ pyramid respectively in the UTWL model are 6.07 and 2.31. Since values of the F-statistic below 5 can indicate very serious finite-sample bias of the instrumental variables estimator towards the least squares estimator, there is reason to be concerned about weakness of the instruments in some cases. Unfortunately, better instruments are not available. The

\footnotetext{
${ }^{19}$ In 2006 euros, this range of values is equivalent to $€ 105,600-€ 162,400$. Using March 2007 exchange rates, it corresponds to $138,800-213,400$ US dollars.
} 
null hypothesis of no difference between the estimates of the ownership variables in the FTSS50, FTSS75, UTWL and UTSS50 models shown in Table 7 and the corresponding instrumental variables estimates was never rejected. Thus, subject to the qualification that for some of the ownership variables the instruments may be weak, there is no evidence of correlation between the ownership variables and the idiosyncratic error in any of these models. There is no evidence that correlation between the idiosyncratic error and the ownership variables in our regressions biases our estimates of the effect of control and cash-flow rights on firm value.

\section{Conclusion}

This paper has shown that the appropriate measurement of firm owners' control rights needs much more attention than it has received in the recent literature on ownership concentration and corporate governance. In most of this literature it has been taken for granted that voting rights are identical to control rights and that the way to measure the control rights of owners who exercise control via a pyramid is to apply the WLP to the various voting rights in the relevant control chains. Both these presumptions are questionable.

We have used a sample of listed German firms to show that the degree of control exerted by the largest owner of a firm and the extent to which this owner's control and cash-flow rights diverge vary greatly according to the control-rights measure used. In order to show that different measures of control rights lead to substantially different economic conclusions, we estimated regression models in which firm share value is explained by alternative measures of control and cash-flow rights, together with other variables. Our results showed that measures of control and cash-flow rights based on the widely-used WLP yielded results that were very different from those obtained using most other ownership measures. According to the WLP-based measures, neither the control nor the cash-flow rights of the largest owner had any effect on firm value, while according to most other models the former had a negative and the latter a positive effect on firm value. The fact that the WLP-based measures gave results that were different from most other ownership measures does not in itself mean that the WLP is an unsatisfactory measure of control rights: the other measures might be incorrect. However, our further investigation of the different 
ownership models strongly suggests that the WLP is unsatisfactory. When we divided the ultimate ownership measures based on the WLP into those in which ownership was and was not exerted via a pyramid, we found that the estimated effects of the largest owner's control and cash-flow rights obtained from observations in which no pyramid was involved were negative and positive respectively, just as in most other models. But the estimates obtained from observations involving pyramids were not significantly different from zero. Thus it is precisely those observations for which the WLP is used to obtain ultimate ownership measures that lead to results that differ from those given by most other ownership models.

Three of the six ownership models that we estimated (the FTSS50, FTSS75 and UTSS50 ones) yielded the consistent result that share value depends negatively on the control rights and positively on the cash-flow rights of the largest owner without any need to distinguish between firms in which ownership was or was not exercised via a pyramid. Two other models (the FTVR and UTWL ones) yielded the same result provided that this distinction was made and attention was paid only to the estimates obtained for firms that were not owned via a pyramid. The UTSS75 model, however, gave results that were inconsistent with the other models and were difficult to interpret. We therefore regard the UTSS75 model as unsatisfactory and conclude that the other five models show that there was a conflict of interest between controlling and non-controlling owners of listed German firms in the early 1990s. The costs resulting from this conflict depend on the extent of the divergence between the largest owner's control and cash-flow rights. The magnitude of these costs implied by the five models differ in an economically, although not statistically, significant way.

What further conclusions can be drawn from our analysis? One is that there are serious reservations about the use of the WLP to measure control rights in the recent empirical literature on corporate governance and ownership structure. Our evidence of the failure of the WLP to provide satisfactory ownership measures is based on data for a single country, and we recognise that studies of other countries have used a similar regression approach in which the results based on use of the WLP have been consistent with the predicted effects of largest owner control and cash-flow rights (Claessens et al. 2002, Barontini and Caprio 2005). But our concerns about the WLP are based on its conceptual weaknesses, discussed in section 2, as well as on its 
poor performance in our regression analysis. Furthermore, the use of the WLP in these other studies has been a maintained hypothesis: there have been, to our knowledge, no attempts to test the WLP against other approaches to the measurement of control rights apart from the one reported in this paper. In our view, insufficient critical scrutiny has been applied to the adoption of the WLP as the standard way of measuring the control rights exercised by owners via a pyramid. The results of studies based on the WLP must be regarded as tentative until they are shown to be robust to alternative measures of control rights.

Another conclusion concerns the view that pyramids exist solely to separate owners' control and cash-flow rights. If this view is correct, it would be expected that measures of control rights derived by tracing ownership through pyramids to ultimate owners would perform better than measures that take no account of pyramid ownership structures. But the results in section 4 of the paper certainly do not suggest that ultimate ownership measures are superior to first-tier ones. Of course, this may simply be because none of the ultimate ownership measures we have used is satisfactory. We have criticised the use of the WLP to measure ultimate owners' control rights on the grounds that it is ad hoc, but the alternative measures of control rights exerted via pyramids that we have proposed, though more plausible than the WLP, are not grounded in a theory of firm ownership. However, any measure of control rights exerted via a pyramid that is so grounded will have to recognise that there may be other reasons for the existence of pyramids in addition to the separation of control and cash-flow rights. These other reasons include minimising transaction costs (Goto 1982), dealing with governance issues involving joint ventures and relationship-specific investments (Emmons and Schmid 1998) or acting as an internal capital market when external capital markets are imperfect (Almeida and Wolfenzon 2006). Treating pyramids that exist for these reasons as if they exist solely to separate control from cash-flow rights is likely to be a source of error. A proper understanding of the role of pyramids in corporate governance requires more attention to be paid to the reasons for the existence of such ownership structures. Our results show that the conflict of interest between controlling and non-controlling owners of listed German firms does depend on the extent to which the largest owner's control and cash-flow rights differ, but it is not obvious that pyramids are a major factor in this separation. 
A recent literature claims that ownership concentration is a consequence of poor legal protection of minority shareholders. Our conclusion that insufficient critical scrutiny has been applied to the use of the WLP as a measure of control rights has potentially important implications for this literature. In the paper which first used the WLP, La Porta et al. (1999) made this claim by showing that widely-held firms (as measured on the basis of the WLP) were, on average, more common in countries with good shareholder protection. For this claim to be convincing, it is necessary to show that the cross-country relationship between ownership concentration and shareholder protection persists when control rights measures other than the WLP are used. In other papers (e.g., La Porta et al. 1998, La Porta et al. 2008), the claim that there is a negative association across countries between ownership concentration and shareholder protection is made using a different concentration measure: the combined cash-flow rights of the three largest shareholders making no allowance for pyramids. However, since the basic hypothesis is that ownership concentration is higher in countries with poor shareholder protection because shareholders need to exercise their control rights via more concentrated ownership, it is not obvious that measuring concentration in terms of cash-flow rights is appropriate. The claim that ownership concentration is a consequence of poor legal protection of shareholders requires an investigation using several different control-rights measures to establish its robustness.

\section{Appendix}

Table A1: Definitions of variables used in the regression analysis

\begin{tabular}{|l|l|}
\hline MTB & $\begin{array}{l}\text { The ratio of market to book value of the firm's equity capital at the } \\
\text { end of the year, obtained from Wegweiser durch deutsche } \\
\text { Unternehmen. }\end{array}$ \\
\hline$C R 1$ (FTVR) & $\begin{array}{l}\text { The largest owner's control rights in the firm measured with no } \\
\text { account of pyramid structures and equating control rights to voting } \\
\text { rights. }\end{array}$ \\
\hline$C R 1$ (FTSS50) & $\begin{array}{l}\text { The largest owner's control rights in the firm measured with no } \\
\text { account of pyramid structures and equating control rights to the } \\
\text { value of the Shapley-Shubik index computed from voting rights } \\
\text { assuming a quota of 50\%. }\end{array}$ \\
\hline$C R 1($ FTSS75) & $\begin{array}{l}\text { The largest owner's control rights in the firm measured with no } \\
\text { account of pyramid structures and equating control rights to the }\end{array}$ \\
\hline
\end{tabular}




\begin{tabular}{|c|c|}
\hline & $\begin{array}{l}\text { value of the Shapley-Shubik index computed from voting rights } \\
\text { assuming a quota of } 75 \% \text {. }\end{array}$ \\
\hline CR1(UTWL) & $\begin{array}{l}\text { The largest owner's control rights in the firm measured using the } \\
\text { WLP to take account of pyramid structures and equating control } \\
\text { rights to voting rights. For firms without a pyramid structure this } \\
\text { equals } C R 1 \text { (FTVR). }\end{array}$ \\
\hline CR1(UTSS50) & $\begin{array}{l}\text { The largest owner's control rights in the firm measured taking } \\
\text { account of pyramid structures by calculating control rights at each } \\
\text { level of the pyramid as the value of the Shapley-Shubik index } \\
\text { computed from voting rights assuming a quota of } 50 \% \text {, and then } \\
\text { using the product of these control rights at different levels as the } \\
\text { ultimate owner's control rights. For firms without a pyramid } \\
\text { structure this equals } C R 1 \text { (FTSS50). }\end{array}$ \\
\hline CR1(UTSS75) & $\begin{array}{l}\text { The largest owner's control rights in the firm measured taking } \\
\text { account of pyramid structures by calculating control rights at each } \\
\text { level of the pyramid as the value of the Shapley-Shubik index } \\
\text { computed from voting rights assuming a quota of } 50 \% \text {, and then } \\
\text { using the product of these control rights at different levels as the } \\
\text { ultimate owner's control rights. For firms without a pyramid } \\
\text { structure this equals } C R 1 \text { (FTSS75). }\end{array}$ \\
\hline$C F 1$ & $\begin{array}{l}\text { The largest owner's cash-flow rights in the firm measured with no } \\
\text { account of pyramid structures. This is the same for all three first-tier } \\
\text { ownership measures, and differs from } C R 1 \text { (FTVR) solely because of } \\
\text { the existence in some firms of different classes of shares with } \\
\text { different voting and dividend rights. }\end{array}$ \\
\hline$C F 1(\mathrm{UTWL})$ & $\begin{array}{l}\text { The cash-flow rights of the largest owner of the firm as measured by } \\
C R 1 \text { (UTWL). For firms with a pyramid structure this is given by the } \\
\text { product of the relevant cash-flow rights at each level of the pyramid, } \\
\text { taking account of the existence of different classes of shares where } \\
\text { necessary. For firms without a pyramid structure this equals } C F 1 \text {. }\end{array}$ \\
\hline$C F 1(\mathrm{UTSS} 50)$ & $\begin{array}{l}\text { The cash-flow rights of the largest owner of the firm as measured by } \\
C R 1 \text { (UTSS50). For firms with a pyramid structure this is given by } \\
\text { the product of the relevant cash-flow rights at each level of the } \\
\text { pyramid, taking account of the existence of different classes of } \\
\text { shares where necessary. For firms without a pyramid structure this } \\
\text { equals } C F 1 \text {. }\end{array}$ \\
\hline$C F 1(\mathrm{UTSS} 75)$ & $\begin{array}{l}\text { The cash-flow rights of the largest owner of the firm as measured by } \\
C R 1 \text { (UTSS75). For firms with a pyramid structure this is given by } \\
\text { the product of the relevant cash-flow rights at each level of the } \\
\text { pyramid, taking account of the existence of different classes of } \\
\text { shares where necessary. For firms without a pyramid structure this } \\
\text { equals } C F 1 \text {. }\end{array}$ \\
\hline CR2 (FTVR) & $\begin{array}{l}\text { The second-largest owner's control rights in the firm measured with } \\
\text { no account of pyramid structures and equating control rights to } \\
\text { voting rights. }\end{array}$ \\
\hline $\begin{array}{l}C R 2 \\
(\mathrm{FTSS} 50)\end{array}$ & $\begin{array}{l}\text { The second-largest owner's control rights in the firm measured with } \\
\text { no account of pyramid structures and equating control rights to the } \\
\text { value of the Shapley-Shubik index computed from voting rights } \\
\text { assuming a quota of } 50 \% \text {. }\end{array}$ \\
\hline$C R 2$ & The second-largest owner's control rights in the firm measured with \\
\hline
\end{tabular}




\begin{tabular}{|c|c|}
\hline (FTSS75) & $\begin{array}{l}\text { no account of pyramid structures and equating control rights to the } \\
\text { value of the Shapley-Shubik index computed from voting rights } \\
\text { assuming a quota of } 75 \% \text {. }\end{array}$ \\
\hline $\begin{array}{l}C R 2 \\
(\mathrm{UTSS} 50)\end{array}$ & $\begin{array}{l}\text { The second-largest owner's control rights in the firm measured } \\
\text { taking account of pyramid structures by calculating control rights at } \\
\text { each level of the pyramid as the value of the Shapley-Shubik index } \\
\text { computed from voting rights assuming a quota of } 50 \% \text {, and then } \\
\text { using the product of these control rights at different levels as the } \\
\text { ultimate owner's control rights. For firms without a pyramid } \\
\text { structure this equals } C R 2 \text { (FTSS50). }\end{array}$ \\
\hline $\begin{array}{l}C R 2 \\
(\text { UTSS75) }\end{array}$ & $\begin{array}{l}\text { The second-largest owner's control rights in the firm measured } \\
\text { taking account of pyramid structures by calculating control rights at } \\
\text { each level of the pyramid as the value of the Shapley-Shubik index } \\
\text { computed from voting rights assuming a quota of } 50 \% \text {, and then } \\
\text { using the product of these control rights at different levels as the } \\
\text { ultimate owner's control rights. For firms without a pyramid } \\
\text { structure this equals } C R 2 \text { (FTSS75). }\end{array}$ \\
\hline CODET & $\begin{array}{l}\text { An indicator variable taking the value of one for firms subject to } \\
\text { Montan codetermination and firms with } 2,000 \text { or more employees, } \\
\text { and zero otherwise. }\end{array}$ \\
\hline $\ln A S S E T S$ & $\begin{array}{l}\text { The natural logarithm of the firm's total assets, obtained from } \\
\text { Wegweiser durch deutsche Unternehmen. }\end{array}$ \\
\hline SALESGR & $\begin{array}{l}\text { The growth rate of the firm's sales in the past year, obtained from } \\
\text { Wegweiser durch deutsche Unternehmen. }\end{array}$ \\
\hline$C A P G R$ & $\begin{array}{l}\text { The growth rate of the firm's book value of equity capital in the past } \\
\text { year, obtained from Wegweiser durch deutsche Unternehmen. }\end{array}$ \\
\hline$D E B T$ & $\begin{array}{l}\text { The firm's total debt as a proportion of its total assets, obtained from } \\
\text { Wegweiser durch deutsche Unternehmen. }\end{array}$ \\
\hline PENSION & $\begin{array}{l}\text { The firm's pension provisions as a proportion of its total assets, } \\
\text { obtained from Wegweiser durch deutsche Unternehmen. }\end{array}$ \\
\hline OTHER & $\begin{array}{l}\text { The firm's other provisions as a proportion of its total assets, } \\
\text { obtained from Wegweiser durch deutsche Unternehmen. }\end{array}$ \\
\hline
\end{tabular}

\section{References}

Almeida, H.V., Wolfenzon, D., 2006. A theory of pyramidal ownership and family business groups. Journal of Finance 61, 2637-2680.

Banzhaf, J.F., 1965. Weighted voting doesn't work: a mathematical analysis. Rutgers Law Review 19, 317-343.

Barclay, M.J., Holderness, C.G., 1989. Private benefits from control of public corporations. Journal of Financial Economics 25, 371-395. 
Barontini, R., Caprio, L., 2005. The effect of family control on firm value and performance: evidence from continental Europe. European Corporate Governance Institute Finance Working Paper 88.

Bebchuk, L.A., Kraakman, R., Trianis, G., 2000. Stock pyramids, cross-ownership and dual class equity: the mechanisms and agency costs of separating control from cash-flow rights. In Morck, R.K. (Ed.). Concentrated Corporate Ownership. Chicago: University of Chicago Press, 295-318.

Becht, M, Bolton, P., Röell, A., 2003. Corporate governance and control. In G.M. Constantinides, G.M., Harris, M., Stulz, R.M. (Eds.). Handbook of the Economics of Finance, Vol. 1. Amsterdam: North-Holland, 1-109.

Bergström, C., Rydqvist, K., 1990. Ownership of equity in dual-class firms. Journal of Banking and Finance 14, 255-269.

Bertrand, M., Mehta, P., Mullainathan, S., 2002. Ferreting out tunnelling: an application to Indian business groups. Quarterly Journal of Economics 117, 121-148.

Chirinko, R.S., Elston, J.A., 2006. Finance, control and profitability: the influence of German banks. Journal of Economic Behavior \& Organization 59, 69-88.

Claessens, S., Djankov, S., Lang, L.H.P., 2000. The separation of ownership and control in East Asian corporations. Journal of Financial Economics 58, 81112.

Claessens, S., Djankov, S., Fan, J.P.H., Lang, L.H.P., 2002. Disentangling the incentive and entrenchment effects of large shareholdings. Journal of Finance $57,2741-2771$.

Demsetz, H., Lehn, K., 1985. The structure of corporate ownership: causes and consequences. Journal of Political Economy 93, 1155-1177. 
Demsetz, H., Villalonga, B., 2001. Ownership structure and corporate performance. Journal of Corporate Finance 7, 209-233.

Dubey, P., Shapley, L.S., 1979. Mathematical properties of the Banzhaf power index. Mathematics of Operations Research 4, 99-131.

Dyck, A., Zingales, L., 2004. Private benefits of control: an international comparison. Journal of Finance 59, 537-600.

Edwards, J.S.S., Weichenrieder, A.J., 2004. Ownership concentration and share valuation. German Economic Review 5, 143-171.

Emmons, W.R., Schmid, F.A., 1998. Universal banking, control rights, and corporate finance in Germany. Federal Reserve Bank of St Louis Review July/August 1998, 19-42.

Faccio, M., Lang, L.H.P., 2002. The ultimate ownership of Western European corporations. Journal of Financial Economics 65, 365-395.

Faccio, M., Lang, L.H.P., Young, L., 2001. Dividends and expropriation. American Economic Review 91, 54-78.

Felsenthal, D.S., Machover, M., 1998. The Measurement of Voting Power. Cheltenham: Edward Elgar.

Franks, J.R., Mayer, C.P., 2001. The ownership and control of German corporations. Review of Financial Studies 14, 943-977.

Goto, A., 1982. Business groups in a market economy. European Economic Review $19,53-70$.

Gugler, K., Yurtoglu, B.B., 2003. Corporate governance and dividend pay-out policy in Germany. European Economic Review 47, 731-758. 
Himmelberg, C.P., Hubbard, R.G., Palia, D., 1999. Understanding the determinants of managerial ownership and the link between ownership and performance. Journal of Financial Economics 53, 353-384.

Jensen, M.C., 1986. Agency costs of free cash flow, corporate finance and takeovers. American Economic Review 76, 323-329.

Jensen M.C., Meckling, W.H., 1976. Theory of the firm: managerial behavior, agency costs and ownership structure. Journal of Financial Economics 3, 305-360.

Johnson, S., La Porta, R., Lopez-de-Silanes, F., Shleifer, A., 2000. Tunneling. American Economic Review 90, 22-27.

La Porta, R., Lopez-de-Silanes, F., Shleifer, A., 1999. Corporate ownership around the world. Journal of Finance 54, 471-517.

La Porta, R., Lopez-de-Silanes, F., Shleifer, A., 2008. The economic consequences of legal origins. Journal of Economic Literature 46, 285-332.

La Porta, R., Lopez-de-Silanes, F., Shleifer, A., Vishny, R.W., 1998. Law and finance. Journal of Political Economy 106, 1113-1155.

La Porta, R., Lopez-de-Silanes, F., Shleifer, A., Vishny, R.W., 2002. Investor protection and corporate valuation. Journal of Finance 57, 1147-1170.

Laeven, L., Levine, R., 2006. Complex ownership structures and corporate valuations. National Bureau of Economic Research Working Paper 12675.

Leech, D., 1988. The relationship between shareholding concentration and shareholder voting power in British companies: a study of the application of power indices for simple games. Management Science 34, 509-527.

Leech, D., 2002. An empirical comparison of the performance of classical power indices. Political Studies 50, 1-22. 
Nenova, T., 2003. The value of corporate voting rights and control: a cross-country analysis. Journal of Financial Economics 68, 325-351.

Owen, G., 1995. Game Theory (third edition). San Diego: Academic Press.

Pohjola, M., 1988. Concentration of shareholder voting power in Finnish industrial companies. Scandinavian Journal of Economics 90, 245-253.

Rydqvist, K., 1986. The Pricing of Shares with Different Voting Power and the Theory of Oceanic Games. Stockholm: Economic Research Institute, Stockholm School of Economics.

Shapley, L.S., Shubik, M., 1954. A method for evaluating the distribution of power in a committee system. American Political Science Review 48, 787-792.

Shleifer, A. Vishny, R.W., 1997. A survey of corporate governance. Journal of Finance 52, 737-783.

Zingales, L., 1994. The value of the voting right: A study of the Milan stock exchange experience. Review of Financial Studies 7, 125-148.

Zwiebel, J., 1995. Block investment and partial benefits of corporate control. Review of Economic Studies 62, 161-185. 


\title{
Control Rights, Pyramids, and the Measurement of Ownership Concentration*
}

\author{
Jeremy S.S. Edwards \\ University of Cambridge \& CESifo
}

Alfons J. Weichenrieder

Goethe University Frankfurt, Oxford University Centre for Business Taxation \& CESifo

May 2009

Addresses of authors

Jeremy S.S. Edwards

Faculty of Economics

University of Cambridge

Sidgwick Avenue

Cambridge CB3 9DD

United Kingdom

Tel: ++44 1223335232

Fax: ++44 1223335475

Email: je12@cam.ac.uk

* Corresponding Author
Alfons J. Weichenrieder*

Goethe University Frankfurt

Grüneburgplatz 1

(Box RuW 45)

60323 Frankfurt (Main)

Germany

Tel: ++496979834788

Fax: ++496979835015

Email: a.weichenrieder@em.uni-frankfurt.de

\footnotetext{
* We thank Dennis Leech for allowing us to use his algorithms for computing voting power indices and for his helpful comments. We also thank Sheilagh Ogilvie and two anonymous referees for helpful comments, and Mara Faccio and Larry Lang for allowing us to use their unpublished data.
} 